Prepared for the U.S. Department of Energy

under Contract DE-AC05-76RL01830

\title{
Summary of TPH Monitoring Conducted at 100-NR-2- 2008 through 2010
}
BG Fritz
JA Stegen
DP Mendoza
AL Bunn
$D$ Yonge
RJ Cameron

September 2010

Pacific Northwest

NATIONAL LABORATORY

Proudly Operated by Battelle Since 1965 


\title{
DISCLAIMER
}

This report was prepared as an account of work sponsored by an agency of the United States Government. Neither the United States Government nor any agency thereof, nor Battelle Memorial Institute, nor any of their employees, makes any warranty, express or implied, or assumes any legal liability or responsibility for the accuracy, completeness, or usefulness of any information, apparatus, product, or process disclosed, or represents that its use would not infringe privately owned rights. Reference herein to any specific commercial product, process, or service by trade name, trademark, manufacturer, or otherwise does not necessarily constitute or imply its endorsement, recommendation, or favoring by the United States Government or any agency thereof, or Battelle Memorial Institute. The views and opinions of authors expressed herein do not necessarily state or reflect those of the United States Government or any agency thereof.

\author{
PACIFIC NORTHWEST NATIONAL LABORATORY \\ operated by \\ BATTELLE \\ for the
}

UNITED STATES DEPARTMENT OF ENERGY

under Contract DE-AC05-76RL01830

Printed in the United States of America
Available to DOE and DOE contractors from the
Office of Scientific and Technical Information,
P.O. Box 62, Oak Ridge, TN 37831-0062;
ph: (865) 576-8401
fax: (865) 576-5728
email: reports@adonis.osti.gov

\author{
Available to the public from the National Technical Information Service, \\ U.S. Department of Commerce, 5285 Port Royal Rd., Springfield, VA 22161 \\ ph: (800) 553-6847 \\ fax: (703) 605-6900 \\ email: orders@ntis.fedworld.gov \\ online ordering: http://www.ntis.gov/ordering.htm
}




\title{
Summary of TPH Monitoring Conducted at 100-NR-2- 2008 through 2010
}

\author{
BG Fritz \\ JA Stegen \\ DP Mendoza \\ AL Bunn \\ D Yonge \\ RJ Cameron
}

September 2010

Prepared for

the U.S. Department of Energy

under Contract DE-AC05-76RL01830

Pacific Northwest National Laboratory

Richland, Washington 99352 



\section{Summary}

Corrosion of diesel fuel transfer lines connecting the large storage tanks and day use tanks resulted in several releases of diesel contamination between 1966 and 1985. Approximately 302,832 L (82,000 gal) of diesel fuel was lost to the vadose zone and aquifer during this time period. The loss of the diesel fuel occurred between 100 and 150 meters from the edge of the Columbia River. An interim solution involved construction of a trench along the shoreline to intercept and accumulate the migrating diesel.

Periodically, the fuel was ignited and allowed to burn in order to remove as much of the diesel as possible before it could enter into the river. Now, a Tri-Party Agreement (TPA) milestone exists to remediate the contaminated groundwater of the 100-NR-2 operable unit to concentrations below the drinking water standard. This report summarizes the results of preliminary investigations conducted to characterize the concentrations of diesel fuel and associate contaminants within the 100-NR-2 operable unit near the Columbia River.

The work conducted for this characterization included soil sampling, water sampling, biota sampling, microbial sampling and passive measurements of in-situ parameters. Water samples were collected along the shoreline, as well as at near-shore groundwater monitoring wells. Soil samples were collected along the shoreline, as well as from a single near-shore borehole. Clam and periphyton samples were collected along the shoreline. Soil samples were analyzed and evaluated for microbial activity. Dissolved oxygen, temperature, specific conductance and water table head elevation were measured in near-shore groundwater monitoring wells. This characterization data has resulted in some insights to the current extent and magnitude of the contamination present in the near shore region that resulted from the diesel fuel spills.

No water samples were collected along the Columbia River shoreline with detectable concentrations of any suspected contaminants. For water samples collected from the near-shore groundwater monitoring wells, benzene and toluene are the only contaminants originating from the diesel fuel spill that appear to approach or exceed any applicable standards. No sediment samples collected as part of this project had concentrations of any contaminants that exceeded any applicable standards. There are several lines of evidence that microbial degradation of the diesel fuel contamination is occurring; there were very low levels of dissolved oxygen measured in the near-shore region, there were low concentrations of nitrate high concentrations and dissolved iron in water samples collected in the near-shore region (resulting from microbial activity), and laboratory studies using site soil confirmed the presence of microbial species capable of degrading diesel.

The general conclusion from this initial characterization is that the concentrations of contaminants associated with the diesel fuel spill may not exceed any applicable regulatory threshold concentrations. Based on this initial characterization, the recommendations for immediate implementation are: a conceptual model should be developed to provide a more complete picture of the contaminant fate and transport; work with regulators to establish the point-of-compliance for the TPH contaminant plume within the 100-NR-2 OU; consider quarterly monitoring of TPH (diesel fraction) as well as volatile organics and PAHs at wells within the suspected boundary of the contaminant plume, consider additional monitoring wells within the suspected boundary of the contaminant plume. Some of these recommendations were initiated in FY2010, and discussed in Appendix D and E. 
Recommendations from the original characterization report were implemented in FY2010; a summary of the findings are included in Appendix D and $\mathrm{E}$ of this revised report. Appendix D includes a preliminary conceptual model, a summary of more extensive TPH monitoring (including at a number of wells drilled since August 2009), and a list of some potential remediation strategies that might prove capable of reducing TPH concentrations in the groundwater at 100-N. Also included (Appendix E) is a laboratory study that provides confirmation of the presence of diesel degrading bacteria, and some evaluation of enhancements that may be beneficial for in-situ remediation strategies. The conclusions from the FY2010 work are that in-situ microbial degradation of TPH is occurring naturally within the plume footprint, and that the aged and weathered nature of the hydrocarbons is a significant factor affecting the contaminant transport and selection of a remedial technology strategy. After screening a number of remedial strategies, the ones that appear to have the most potential for success at $100-\mathrm{N}$ are In Situ Chemical Oxidation_(Fenton's oxidation), Enhanced biodegradation, Monitored natural attenuation (MNA), and Initially enhanced monitored natural attenuation. 


\section{Contents}

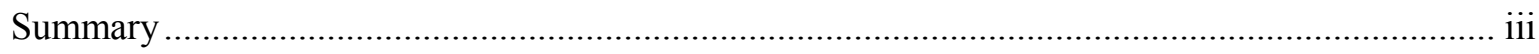

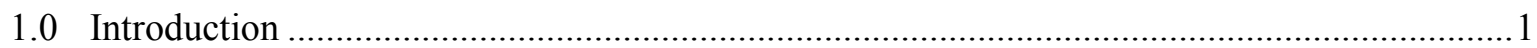

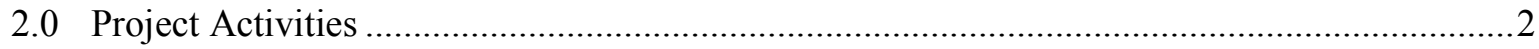

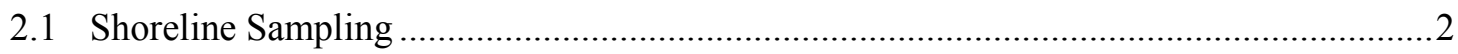

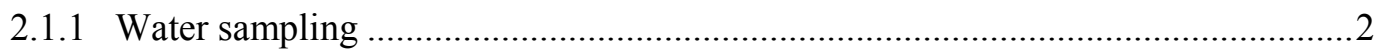

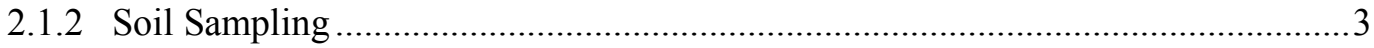

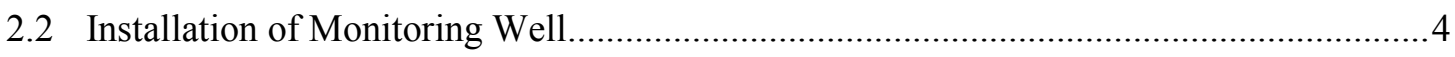

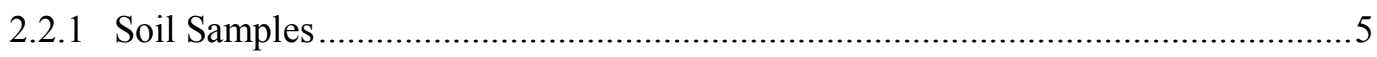

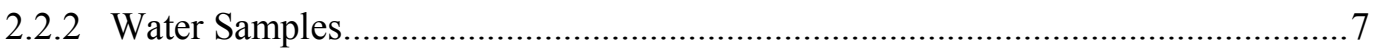

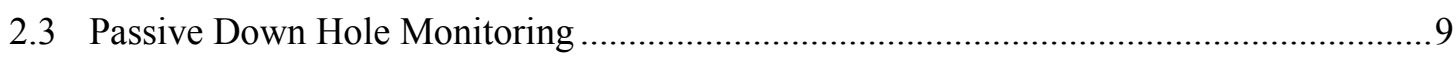

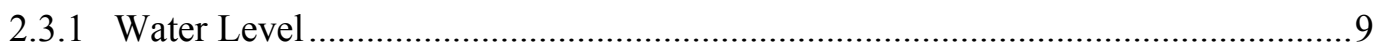

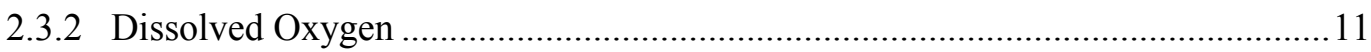

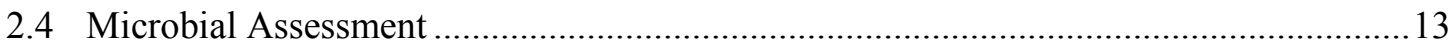

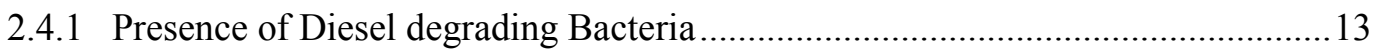

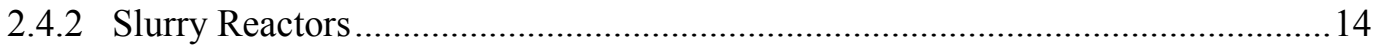

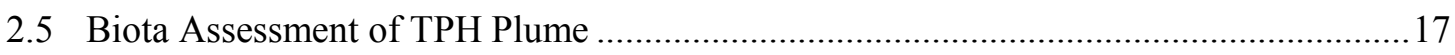

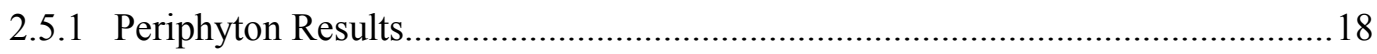

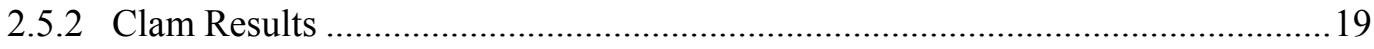

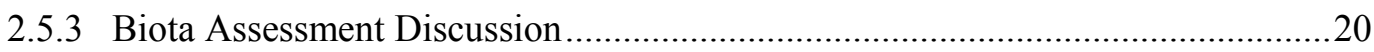

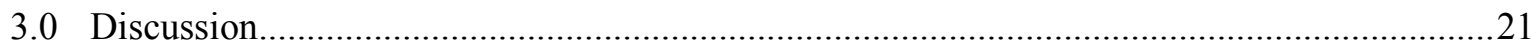

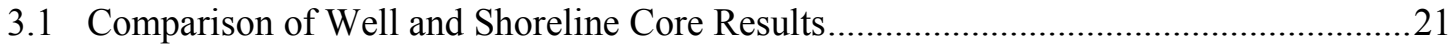

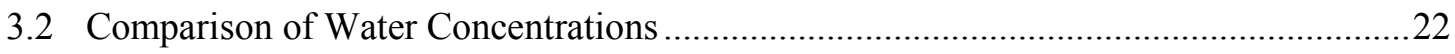

3.3 Comparison of Water, Sediment and Biota Concentrations.........................................23

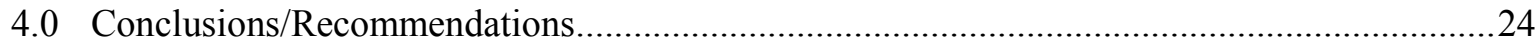

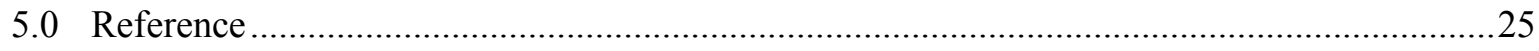

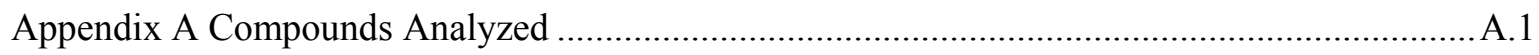

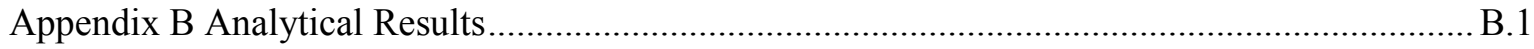

Appendix C Drilling Information for Monitoring Well 199-N-173 …....................................... C.1 


\section{Figures}

1 Concentrations and Screening Results for TPH Measured in Samples Collected During

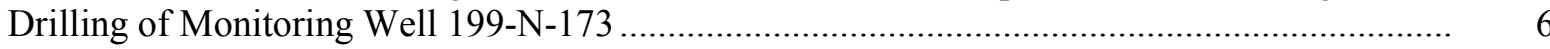

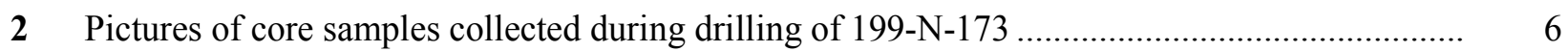

3 Concentrations of Selected Compounds Measured in Water Samples Collected During

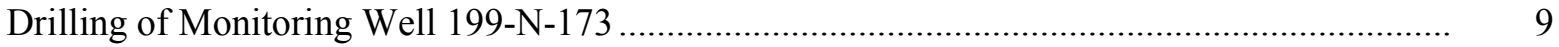

$4 \quad$ Locations with Water Level Monitoring Instrumentation Installed in 2008............................. 10

5 Groundwater Head Elevation Measured in the Vicinity of the Diesel Contamination Plume...... 11

6 Dissolved Oxygen Concentrations Measured in 199-N-96 ...................................................... 12

7 Dissolved Oxygen Measured at Two Locations in 199-N-96A; Near the Top and Bottom of

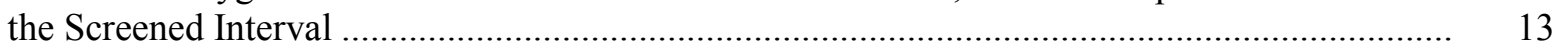

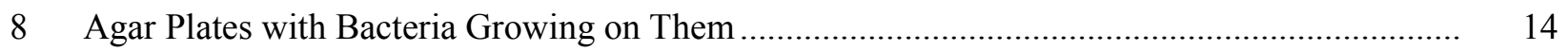

9 Results for Multiple Sets of Slurry Reactor Tests.................................................................. 16

10 Periphyton and Clam Sampling Locations - September 2008 ............................................... 17

11 Fluorathene Concentrations Measured in Periphyton Samples Collected Along the 100-N Shoreline

12 Concentrations of TPH-Dx measured in Sediment Samples Collected during Drilling of 199-N-173 and Along the Shoreline.

\section{Tables}

1 Sampling Locations for Water Samples Collected in 2008 ................................................... 2

2 Shoreline Soil Sampling Names and Locations ................................................................. 3

3 Maximum Measured Concentrations in Sediment Samples Collected Along the 100-N Shoreline and Associated MTCA Concentrations .................................................................. 4

4 Depths of samples collected during installation of monitoring well 199-N-173 ....................... 4

5 Maximum Measured Concentrations in Soil Samples Collected During Drilling of Monitoring Well 199-N-173 and Associated MTCA Concentrations ......................................... 7

6 Maximum Measured Concentrations in Water Samples Collected During Drilling of Monitoring Well 199-N-173 and Associated Regulatory Standards ......................................... 8

7 Most Probable Number Results for Bacteria Growth Using Two Sediment Samples Collected During Drilling of Monitoring Well 199-N-173

8 Average PAH Results for Periphyton Samples Collected within the 100 N TPH Plume and at an Upstream Reference Location - September 2008 ........................................................... 18

9 Average PAH Results for Clam Tissue Samples Collected within the 100 N TPH Plume and at an Upstream Reference Location - September 2008.

10 Average Measured Concentrations of Several Key Analytes from Samples Collected in Recent Years in Monitoring Wells within the Suspected Footprint of the Diesel Contamination Plume 


\subsection{Introduction}

The Hanford Site, located in southeastern Washington State, was once home to Cold War weapons grade plutonium production. Over the last fifteen years, the Site's function has shifted from production and operation to remediation and decontamination. At the 100-N Area, the 100-NR-1 operable unit (OU) contains all the source waste sites located within the main industrial area around the 100-N Reactor and the Hanford Generating Plant, and includes the surface sediments and shallow subsurface soil associated with the disposal trenches. The 100-NR-2 OU contains the contaminated groundwater and aquifer. One contaminant still unaddressed in the 100-NR-2 OU is residual diesel contamination and associated contaminants. During operation of the 100-N reactor, number 2 diesel fuel was used for firing igniters in boilers and the operation of different types of machinery. Diesel was transferred from these large storage tanks daily via a four inch transfer pipe to smaller day use tanks. Corrosion of the transfer lines connecting the large storage tanks and day use tanks resulted in several incidents that occurred between 1966 and 1985; release of approximately 302,832 L (82,000 gal) of diesel fuel. These unplanned released are documented in the Waste Information Data System database with the following identification numbers: UPR-100-N-17, UPR-100-N-19, and UPR-100-N-20. The leak was identified by a discrepancy in the inventory of diesel. Two other documented spills (in 1973 and 1985) resulted in approximately 200 additional gallons of diesel fuel being lost to the environment.

The loss of the diesel fuel occurred between 100 and 150 meters from the edge of the Columbia River. Some time later diesel was observed to be entering the river. In order to alleviate this problem, a trench was excavated along the shoreline to intercept and accumulate the migrating diesel. Periodically, the fuel was ignited and allowed to burn in order to remove as much of the diesel as possible before it could enter into the river.

Although some mitigating actions have taken place since the initial leak, sediment and groundwater in the vicinity of the $100 \mathrm{~N}$ reactor have been found to be contaminated with diesel fuel and its associated breakdown products. In recent years, some limited environmental monitoring for total petroleum hydrocarbons (TPH) and other organic contaminants occurred along the Columbia River shoreline in the vicinity of the 100-NR-2 operable unit. The 100-NR-2 is the operable unit that encompasses the groundwater beneath and near the $100 \mathrm{~N}$ reactor.

A shoreline risk assessment was performed 2005, but has not yet been published. This investigation evaluated radiological, metal and organic contaminants in sediment, water and biota. No detectable levels of TPH were found in the water samples collected near the riverbed surface, but low concentrations were detected in some sediment samples.

In February 2007, aquifer tubes were installed along the Columbia River shoreline within the suspected TPH plume discharge area (Mendoza et al. 2007). One round of water samples were collected and analyzed for TPH-Dx (diesel fraction). Concentrations ranged from undetected $(<0.1 \mathrm{mg} / \mathrm{L})$ to $0.63 \mathrm{mg} / \mathrm{L}$. These preliminary samples provided evidence for the location of the TPH plume centerline.

A Tri-Party Agreement (TPA) milestone exists to remediate the contaminated groundwater of the 100-NR-2 operable unit to concentrations below the drinking water standard. This report summarizes the results of preliminary investigations conducted to identify potential non-radiological contaminants of concern. 


\subsection{Project Activities}

Under this project, a variety of activities were conducted in order to assess the extent of the TPH plume, improve the understanding of contaminant fate and transport, and to begin to assess the potential impact of this contamination to the river. Each activity is discussed separately in the following sections, with a discussion of the integrated results at the end.

\subsection{Shoreline Sampling}

\subsubsection{Water sampling}

Two water sampling events were conducted along the shoreline during FY08. These sampling events occurred May 19 and September 25, 2008. Samples were collected from 11 aquifer tubes along the shore (Table 1) and the Columbia River. Typical aquifer tube sampling procedures were used (Mendoza et al. 2007). These samples were analyzed for a number of constituents (Appendix A). Samples were collected as bulk water in amber glass jars and immediately placed on ice; acidification of the sample occurred within 24 hours for analytes requiring acidification. Field parameters (specific conductance, temperature, dissolved oxygen, etc.) were also measured with hand held instruments and recorded for all samples collected. Although some samples collected had measured specific conductance and dissolved oxygen levels typical of groundwater, all 24 samples analyzed in FY08 had concentrations of organic constituents below detectable concentrations.

Table 1. Sampling Locations for Water Samples Collected in 2008 (not all locations sampled each time)

\begin{tabular}{cccc}
\hline Aquifer Tube Name & Latitude & Longitude & Screen Elevation $(\mathrm{m})$ \\
\hline N0A-US25-167cm & 46.67670 & -119.56980 & 116.0 \\
N-116mARRAY-0A-50cm & 46.67707 & -119.56975 & 117.2 \\
N-116mARRAY-0A-81cm & 46.67707 & -119.56975 & 116.8 \\
N-116mARRAY-0A & 46.67707 & -119.56975 & 116.0 \\
N-116mARRAY-0A-250cm & 46.67707 & -119.56975 & 115.2 \\
N-116mARRAY-0B-60cm & 46.67709 & -119.56980 & 116.0 \\
N0A-DS15-80cm & 46.67715 & -119.56966 & 116.8 \\
N0A-DS15-160cm & 46.67715 & -119.56966 & 116.0 \\
N0A-DS15B-60cm & 46.67717 & -119.56970 & 115.9 \\
N0A-DS25-76cm & 46.67723 & -119.56958 & 116.8 \\
N0A-DS25-149cm & 46.67723 & -119.56958 & 116.1 \\
N0A-DS25-223cm & 46.67723 & -119.56958 & 115.3 \\
N0A-DS50-149cm & 46.67742 & -119.56939 & 116.0 \\
Columbia River $(\sim 10 \mathrm{ft}$ offshore $)$ & NA & NA & $\sim 116.5$ \\
\hline
\end{tabular}




\subsubsection{Soil Sampling}

Soil samples were collected at various depths along the Columbia River shoreline in FY09. These samples were analyzed for the presence of Diesel Range Organics (DRO), metals, and volatile organic compounds. The raw data for these samples is included in Appendix A. Nine samples were collected at four locations, with samples being collected from multiple depths at some of the locations (Table 2). A coring tool (Marco-Core, Geoprobe ${ }^{\circledR}$, Salins, KS) was used for sample collection. This tool collected a 2inch core in a polyethylene core liner. After collection, the sample was immediately transferred to appropriate sample containers for the various analytes, as provided by the sub-contracted analytical laboratory. The sample containers were then placed on ice prior to shipment to the analytical laboratory for analysis.

None of the compounds detected in shoreline soil exceeded the Model Toxics Control Act (MTCA) Method A soil cleanup levels for unrestricted use (Table 740-1, WAC 173-340-740). Only TPH exceeded 25\% of the MTCA Method A values (Table 3; Appendix B), indicating it is likely the only compound that could possibly exceed the soil threshold concentration along the Columbia River shoreline.

Table 2. Shoreline Soil Sampling Names and Locations

\begin{tabular}{cccc}
\hline Sediment Sample ID & Latitude & Longitude & Sample Elevation (m) \\
\hline TPHA1-2ft & 46.677027 & 119.569626 & 118.8 \\
\hline TPHA2-1.5ft & 46.677033 & 119.569646 & 118.3 \\
\hline TPHA2-4ft & 46.677033 & 119.569646 & 117.5 \\
\hline TPHA2-5ft & 46.677033 & 119.569646 & 117.2 \\
\hline TPHA3-2ft & 46.677048 & 119.569686 & 117.3 \\
\hline TPHA3-4ft & 46.677048 & 119.569686 & 116.7 \\
\hline TPHB1-2ft & 46.677096 & 119.569555 & 118.1 \\
\hline TPHB1-4ft & 46.677096 & 119.569555 & 117.5 \\
\hline TPHB1-5ft & 46.677096 & 119.569555 & 117.2 \\
\hline
\end{tabular}


Table 3. Maximum Measured Concentrations in Sediment Samples Collected Along the 100-N Shoreline and Associated MTCA Concentrations

\begin{tabular}{lcc}
\hline Compound & Maximum Concentration $(\mathrm{mg} / \mathrm{kg})$ & MTCA Clean-up Level $^{(\mathrm{a})}(\mathrm{mg} / \mathrm{kg})$ \\
\hline Benzene & 0.0032 & 0.03 \\
Ethylbenzene & 0.00013 & 6 \\
Lead & 6.4 & 250 \\
MTBE & 0.000083 & 0.1 \\
Fluoranthene & 0.015 & $0.1^{(\mathrm{b})}$ \\
Pyrene & 0.024 & $0.1^{(\mathrm{b})}$ \\
Toluene & 0.00073 & 7 \\
TPH- DRO & 1200 & 2000 \\
Xylenes $^{(\mathrm{c})}$ & 0.00072 & 9 \\
\hline
\end{tabular}

(a) Method A Unrestricted Land Use Cleanup Levels. From Table 740-1 of WAC Code 173-340-740

(b) Value for Benzo(a)pyrene used for all PAH's, as instructed in the WAC Code

(c) Sum of $\mathrm{m}, \mathrm{p}$ and o xylenes

\subsection{Installation of Monitoring Well}

A monitoring well (199-N-173) was installed at the river's edge to assess the vertical extent of contaminated soil. No other contaminant concentration in soil data was available in the area where the TPH contamination plume is assumed to discharge to the river. Water samples and soil samples were collected at various depths below ground surface during well installation (Table 4). The well was completed with a 6-inch inner casing, and screened between 10.1 and 25.1 feet below ground surface. The results of the sampling indicate that the TPH contamination was primarily limited to the top portion of the aquifer and the "smear zone," or the portion of the vadose zone that is occasionally saturated as a result of a fluctuating river stage.

Table 4. Depths of samples collected during installation of monitoring well 199-N-173

\begin{tabular}{cc}
\hline Soil Core Sample Collection Depths (ft bgs) & Water Sample Collection Depths (ft bgs) \\
\hline $9.9-12$ & $19^{\mathrm{a}}$ \\
$12.5-14.5$ & 23.2 \\
$15-16.5^{(\mathrm{a})}$ & 33 \\
$17.5-20$ & 43 \\
$24.5-27$ & \\
$30-31.5$ & \\
$34.5-37$ & \\
$39.5-42$ & \\
$44.6-47.1$ & \\
\hline
\end{tabular}

(a) duplicate sample collected at this depth 


\subsubsection{Soil Samples}

Two types of soil samples were collected during the drilling of 199-N-173; grab samples and core samples. Grab samples were collected nominally every 2.5 feet between 9.5 and 45 feet below ground surface (bgs). Grab samples were analyzed for TPH using a field screening kit that detected a positive presence of diesel above $15 \mathrm{mg} / \mathrm{kg}$. These screening kits only provided an indication of TPH above the threshold; there was no estimate of the relative concentration provided by the screening kit. Two foot long core samples were collected continuously between 10 and 20 feet bgs, then every 5 feet between 25and 45-feet bgs. Core samples were analyzed for TPH, metals, and volatile organic compounds by the Waste Sampling and Characterization Facility (WSCF) (Appendix B).

The field screening for TPH indicated the presence of diesel contamination between 9.5 and 20 feet bgs at concentrations exceeding $15 \mathrm{mg} / \mathrm{kg}$. This was consistent with the results from the core samples (Figure 1). The core sample results indicate that the concentrations increased with depth up to 20 feet bgs. Below 20 feet bgs, the TPH concentrations in sediment were below detectable concentrations ( $\sim 4 \mathrm{mg} / \mathrm{kg}$ ). The metals concentrations observed in core samples collected from 199-N-173 appeared to vary some with depth; however, the variation was probably associated with lithological changes rather than the presence of contaminants (Appendix C). Core samples were analyzed for 99 organic compounds; only 7 were measured at detectable concentrations in any of the core samples (Table 5, Appendix B). These concentrations were at or below the MTCA Method A soil cleanup levels for unrestricted use (Table 740-1, WAC 173-340-740) for the detectable compounds. It should be emphasized that the data presented here is for a handful of samples collected from a single location; further sampling from boreholes in this area may reveal different information.

Pictures of the core samples indicated some irregularities at 20 feet bgs. Primarily, the color of the soil became grey and had a slimy appearance (Figure 2). However, the grain size distribution did not appear significantly different. This same grey color was observed in several soil samples collected along the shoreline. During drilling, there was a diesel odor noticed at the 20 foot depth (Appendix C). This was consistent with diesel odor associated with grey discoloration noted in samples collected along the Columbia River shoreline. 


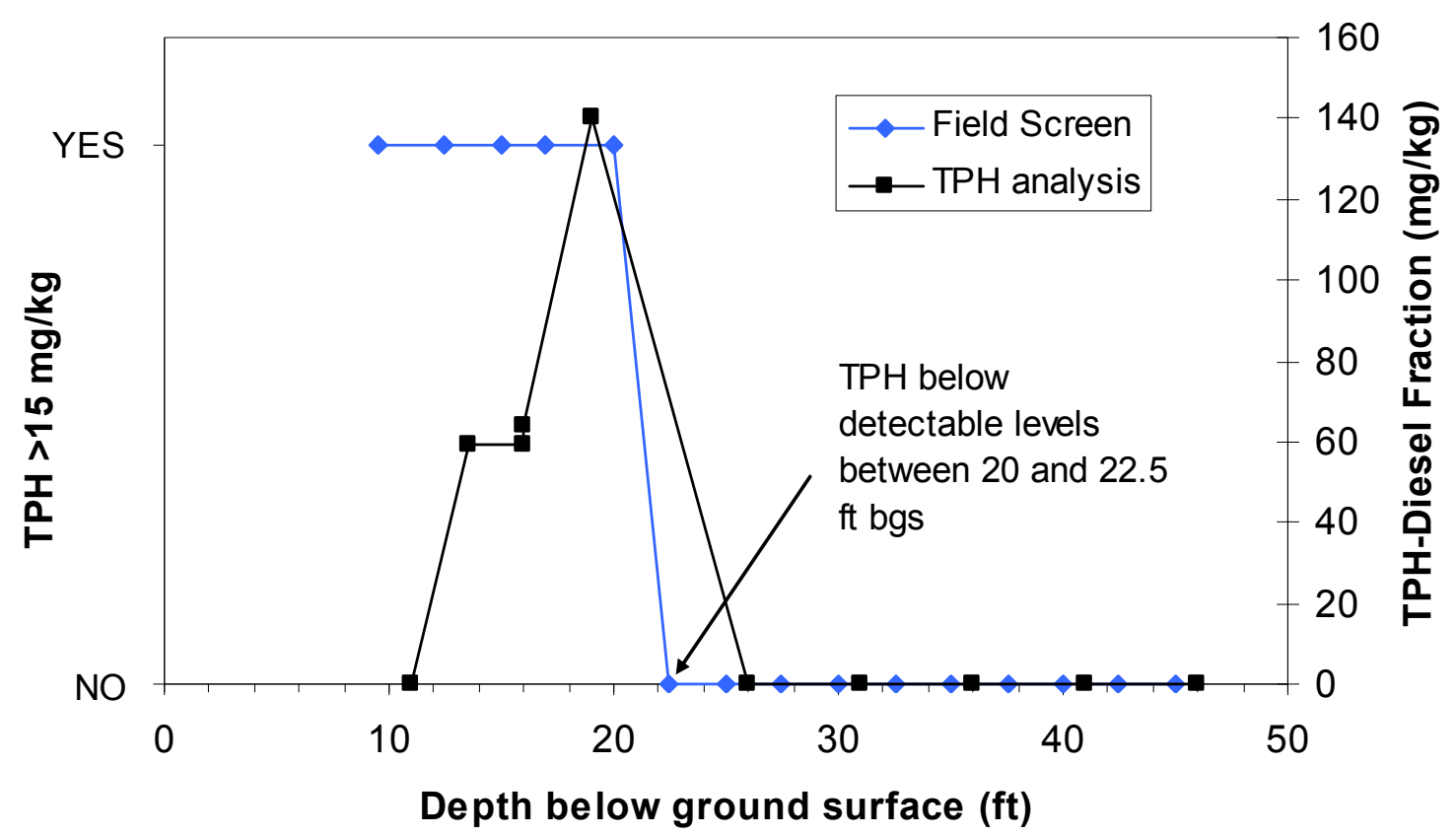

Figure 1. Concentrations and Screening Results for TPH Measured in Samples Collected During Drilling of Monitoring Well 199-N-173
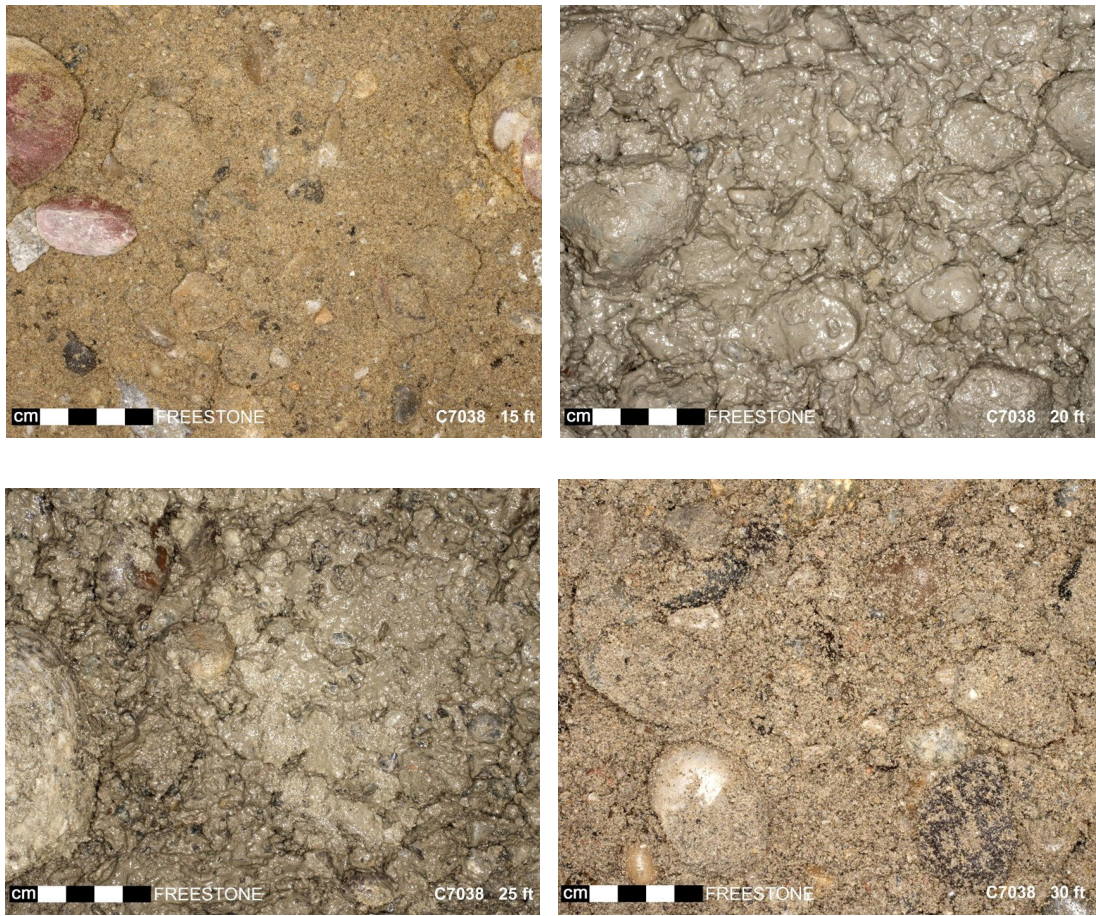

Figure 2. Pictures of core samples collected during drilling of 199-N-173 
Table 5. Maximum Measured Concentrations in Soil Samples Collected During Drilling of Monitoring Well 199-N-173 and Associated MTCA Concentrations

\begin{tabular}{lccc}
\hline \multicolumn{1}{c}{ Compound } & $\begin{array}{c}\text { Maximum Concentration } \\
(\mathrm{mg} / \mathrm{kg})\end{array}$ & $\begin{array}{c}\text { Depth of Maximum } \\
(\mathrm{ft} \text { bgs })\end{array}$ & $\begin{array}{c}\text { MTCA Clean-up Level }^{(\mathrm{a})} \\
(\mathrm{mg} / \mathrm{kg})\end{array}$ \\
\hline TPH- DRO & 140 & $17.5-20$ & 2000 \\
Benzene & 0.003 & $15-16.5$ & 0.03 \\
Ethylbenzene & 0.0025 & $39.5-42$ & 6 \\
Toluene & 0.005 & $15-16.5$ & 7 \\
2-Butanone (MEK) & 0.0073 & $15-20^{(\mathrm{b})}$ & $\mathrm{NA}$ \\
Bis(2-Ethylhexyl)phthalate & 1.4 & $15-20^{(\mathrm{b})}$ & $\mathrm{NA}$ \\
Styrene & 0.0067 & $15-16.5$ & $\mathrm{NA}$ \\
Xylenes $^{(\mathrm{c})}$ & $<0.001$ & $\mathrm{NA}$ & 9 \\
\hline
\end{tabular}

(a) Method A Unrestricted Land Use Cleanup Levels. From Table 740-1 of WAC Code 173-340-740

(b) Similar concentrations at 15-16.5 and 17.5-20 foot intervals

(c) Sum of $m, p$ and o xylenes

\subsubsection{Water Samples}

Five aqueous samples were collected during drilling activities. These samples were collected from the top of the water table ( 2 samples), and then at various depths (Appendix B). For evaluation, results from three depths were evaluated; results from the two samples at the top of the aquifer were averaged into a single result, and the sample at the bottom of the well was from a different lithologic material, and was not considered representative. In general, chemical analysis of samples collected from the top of the aquifer identified the presence of TPH and provided evidence of microbial activity, and deeper samples indicated a decrease of TPH contamination with depth (Figure 3). At the top of the aquifer, TPH, iron, and manganese were elevated relative to the lower portion of the aquifer. The high iron and manganese concentrations are indicative of microbial activity; aqueous iron concentrations increase as bacteria use $\mathrm{Fe}(\mathrm{III})$ as an electron acceptor and reduce it to Fe(II), which is soluble in water. Manganese can be reduced in a similar manner, but is not present in sediment at the same quantity as iron. Microbial use of iron and manganese as an electron acceptor is not as thermodynamically favorable as the use of oxygen and nitrate. Dissolved oxygen levels in groundwater have been shown to be quite low (see section 3.3). Similarly, nitrate concentrations were very low at the top of the aquifer, and increased with depth. These data all indicate that bacteria are actively using the TPH contamination near the top of the aquifer as a carbon source. As the TPH concentrations decrease, the microbial activity also decreases, as evidenced by higher measured nitrate concentrations, and lower iron and manganese concentrations with increasing depth. Microbial activity and TPH degradation were confirmed by slurry reactor tests (see Section 3.4).

Other contaminants were also detected in aqueous samples collected from 199-N-173 during drilling. Several of these contaminants were detected at concentrations that approach or exceed the Groundwater Quality Criteria or Drinking Water Standards established by the WAC Code (173-200-040 and 246-290-310, respectively) (Table 6). Several of these contaminants do not originate from the diesel fuel spill (nitrate, sulfate, specific conductance, strontium-90), and iron is likely only high because of microbial activity (this iron would be insoluble in oxygenated water). It is also important to note that 
having sample results that exceed the concentrations established by the WAC Code does not necessarily mean that the standard is being exceeded at this point in time. These were depth discrete samples from an uncompleted well collected for characterization purposes; future sample collection efforts will use appropriate sampling methodology from the fully screened well to determine compliance.

Table 6. Maximum Measured Concentrations in Water Samples Collected During Drilling of Monitoring Well 199-N-173 and Associated Regulatory Standards

\begin{tabular}{|c|c|c|c|c|}
\hline Constituent & $\begin{array}{l}\text { Groundwater Quality } \\
\text { Criteria }(\mathrm{mg} / \mathrm{L})^{(a)}\end{array}$ & $\begin{array}{c}\text { Drinking Water MCL } \\
(\mathrm{mg} / \mathrm{L})^{(\mathrm{b})}\end{array}$ & $\begin{array}{c}\text { Maximum } \\
\text { Concentration }(\mathrm{mg} / \mathrm{L})^{(\mathrm{c})}\end{array}$ & $\begin{array}{c}\text { Depth of } \\
\text { Maximum (ft) }\end{array}$ \\
\hline Benzene & 0.001 & 0.005 & 0.0033 & 19 \\
\hline Nitrate (as N) & 10 & 10 & 11.8 & 33 \\
\hline Iron & 0.3 & 0.3 & 42 & 19 \\
\hline Sulfate & 250 & 250 & 306 & 19 \\
\hline Toluene & NA & 1 & 2.6 & 19 \\
\hline Xylene's (total) & NA & 10 & $\mathrm{ND}(<0.001)$ & ND \\
\hline Ethylbenzene & NA & 0.7 & $\mathrm{ND}(<0.001)$ & ND \\
\hline TPH- Dx & NA & NA & 4.3 & 19 \\
\hline Sp. Conductance & NA & $700 \mu \mathrm{S} / \mathrm{cm}$ & $1420 \mu \mathrm{S} / \mathrm{cm}$ & 19 \\
\hline Strontium-90 $90^{(\mathrm{d})}$ & $8 \mathrm{pCi} / \mathrm{L}$ & $8 \mathrm{pCi} / \mathrm{L}$ & $23 \mathrm{pCi} / \mathrm{L}$ & 19 \\
\hline
\end{tabular}

(a) WAC Code 173-200-040-Table 1

(b) WAC Code 246-290-310-Table 4, 40 CFR 141.61, 40 CFR 141.66

(c) Measured in 199-N-173 during drilling

(d) Radiological analysis conducted was, but is not discussed in this report

NA no value provided for this contaminant

ND concentration below the analytical detection limit 


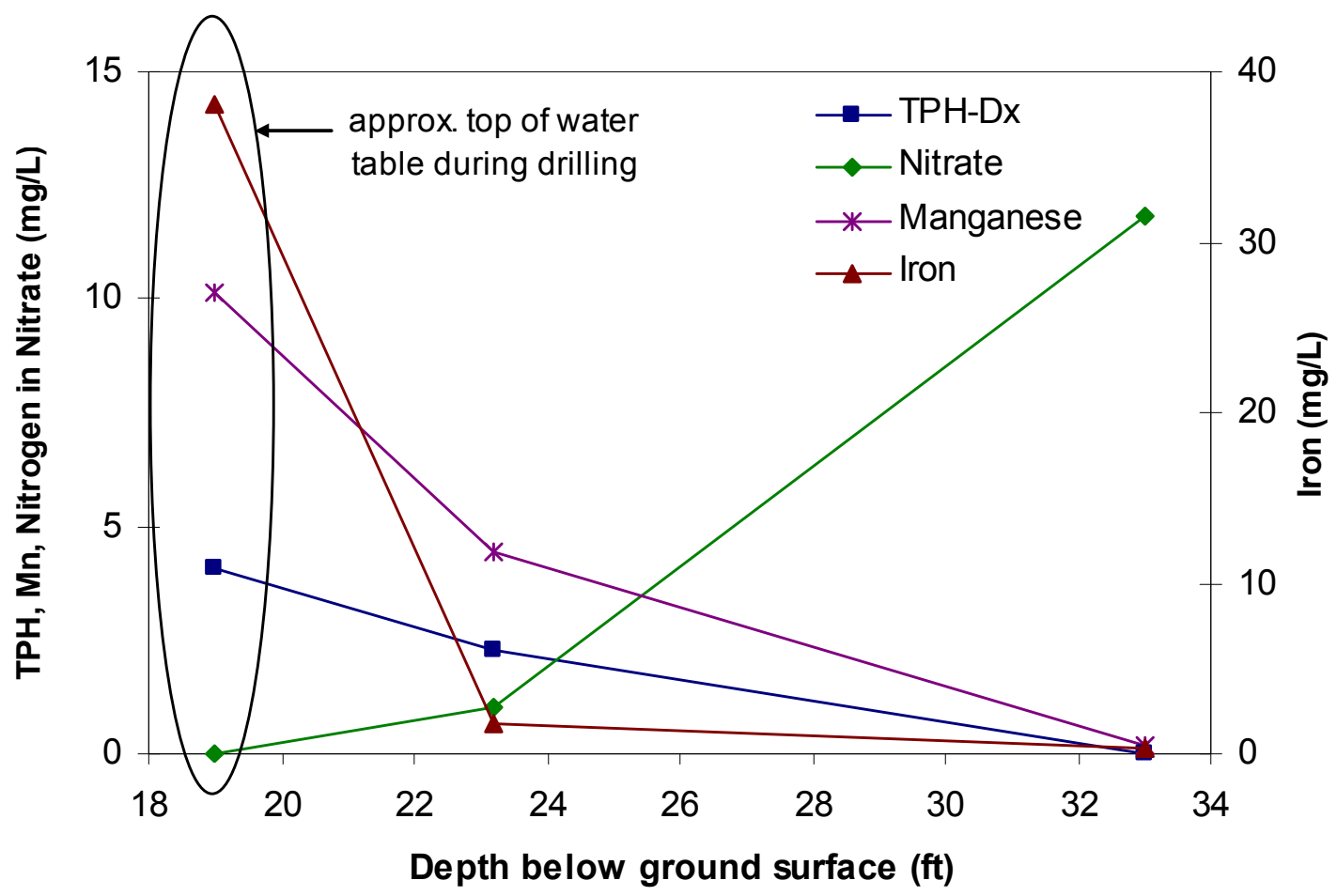

Figure 3. Concentrations of Selected Compounds Measured in Water Samples Collected During Drilling of Monitoring Well 199-N-173

\subsection{Passive Down Hole Monitoring}

\subsubsection{Water Level}

Five groundwater wells in the vicinity of the TPH contaminant plume were instrumented with water level sensors (Figure 4). This was done to gain a better understanding of the groundwater gradient in this portion of the 100-N Area, and to evaluate the influence of fluctuating river stage at various distances away from the river. The instruments were PT2X temperature/pressure sensors housed within a selfcontained data logger (Instrumentation Northwest, Kirkland, WA). Measurements were recorded every 15 minutes, beginning in early January 2009. Water depth was converted to head elevation by collecting periodic depth to water readings from vertically controlled points (top-of-casing). Hourly river stage elevation measurements were obtained from the Hanford Site Virtual Library. The data indicate that the water head elevation in all of the wells responded to changes in river stage, even 330 meters inland from the river (199-N-56). As expected, the wells closer to the river responded very rapidly to changes in river stage, while wells farther from the river responded slower, and with a dampened response (Figure 5). 


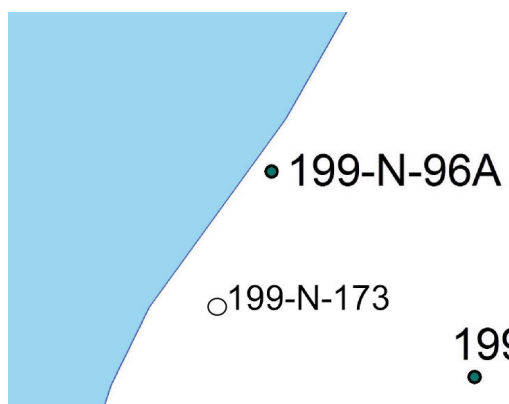

$199-\mathrm{N}-19$

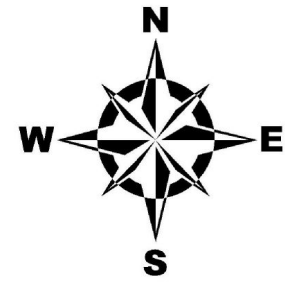

199-N-56 $\square$

Approximate estimated spill location

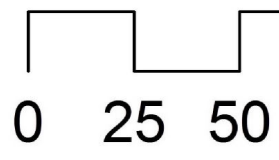

Figure 4. Locations with Water Level Monitoring Instrumentation Installed in 2008 (199-N-173 shown for reference only; water level monitoring began summer 2009). 


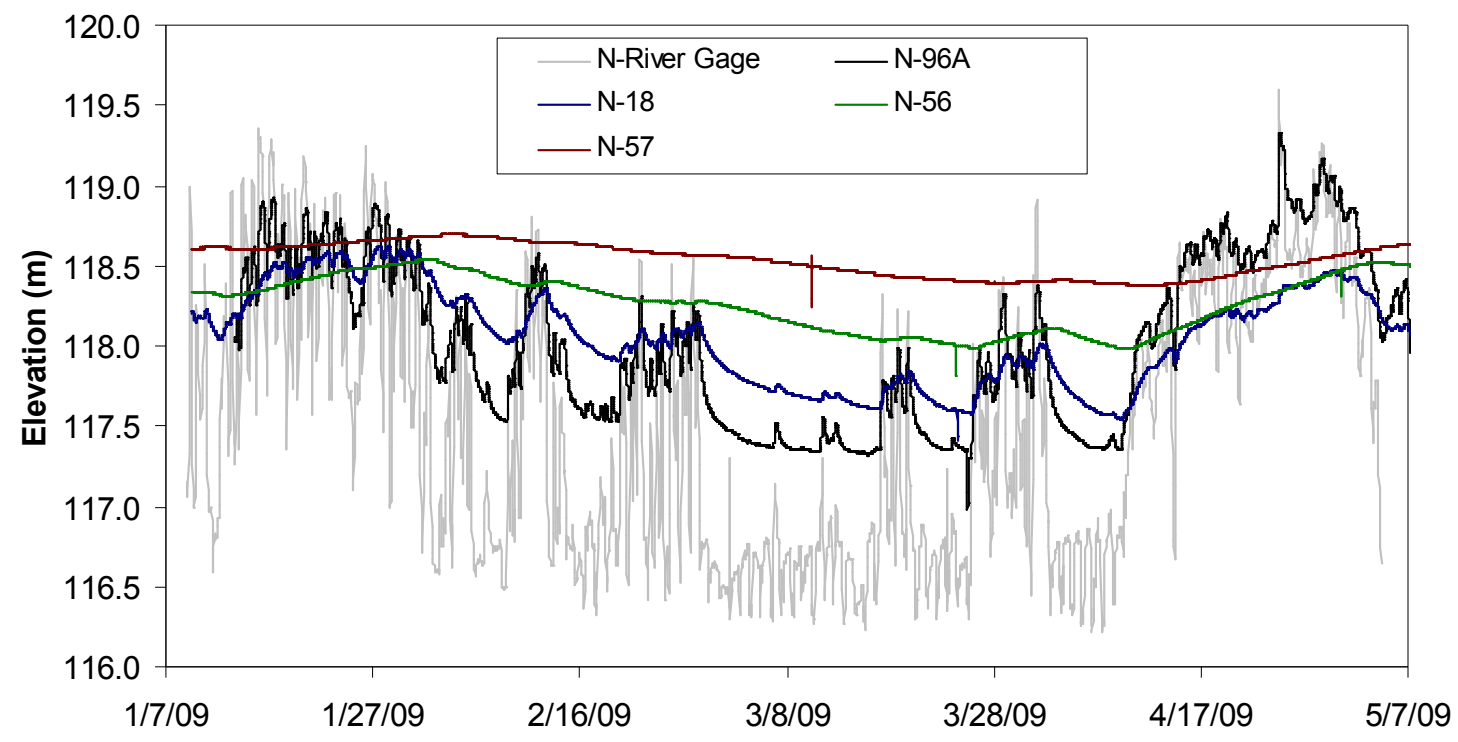

Figure 5. Groundwater Head Elevation Measured in the Vicinity of the Diesel Contamination Plume. Data from 199-N-19 not shown as it was nearly identical to data from 199-N-18.

\subsubsection{Dissolved Oxygen}

Dissolved oxygen concentrations were monitored in-situ at several locations within the contaminant plume during FY08 and FY09. The largest data set was collected at 199-N-96A between July 2008 and February 2009. Other monitoring points included a piezometer installed along the shoreline and monitoring well 199-N-173. The results clearly indicate the presence of groundwater with low dissolved oxygen concentrations. For example, in 199-N-173, the dissolved oxygen concentration was below $0.1 \mathrm{mg} / \mathrm{L}$ for the entire four week monitoring period. The concentrations of dissolved oxygen measured at the two monitoring wells are lower than typically observed in near-shore groundwater wells within the $100-\mathrm{N}$ Area. The low DO concentrations observed likely indicate that microbial activity is occurring. The dissolved oxygen concentrations observed in the near shore piezometer (nominally $8 \mathrm{mg} / \mathrm{L}$ ) were typical of mixed river water and groundwater. No evidence of reduced dissolved oxygen concentration was observed at the shoreline; however, the piezometer was likely not placed far enough into the river. When river stage dropped low enough for potential groundwater discharge to the river, the piezometer was dry.

In 199-N-96A it is evident that the dissolved oxygen concentrations are impacted by seasonal river stage conditions as well as hourly river stage conditions (Figure 6). During the late summer, when the river stage is beginning to descend from the yearly high, dissolved oxygen concentrations were moderately high, indicating intrusion of oxygenated river water. This is supported by the lower specific conductance observed during this time. As the river stage decreased, the specific conductance increased, indicating a higher groundwater to river water mixing ratio. During this time, the dissolved oxygen concentration decreased below $1 \mathrm{mg} / \mathrm{L}$. Although the seasonal pattern of dissolved oxygen response to river stage is typical (high river stage = high dissolved oxygen), the hourly fluctuations of dissolved oxygen are inversely proportional. When river stage increases, the dissolved oxygen concentration decreases. 


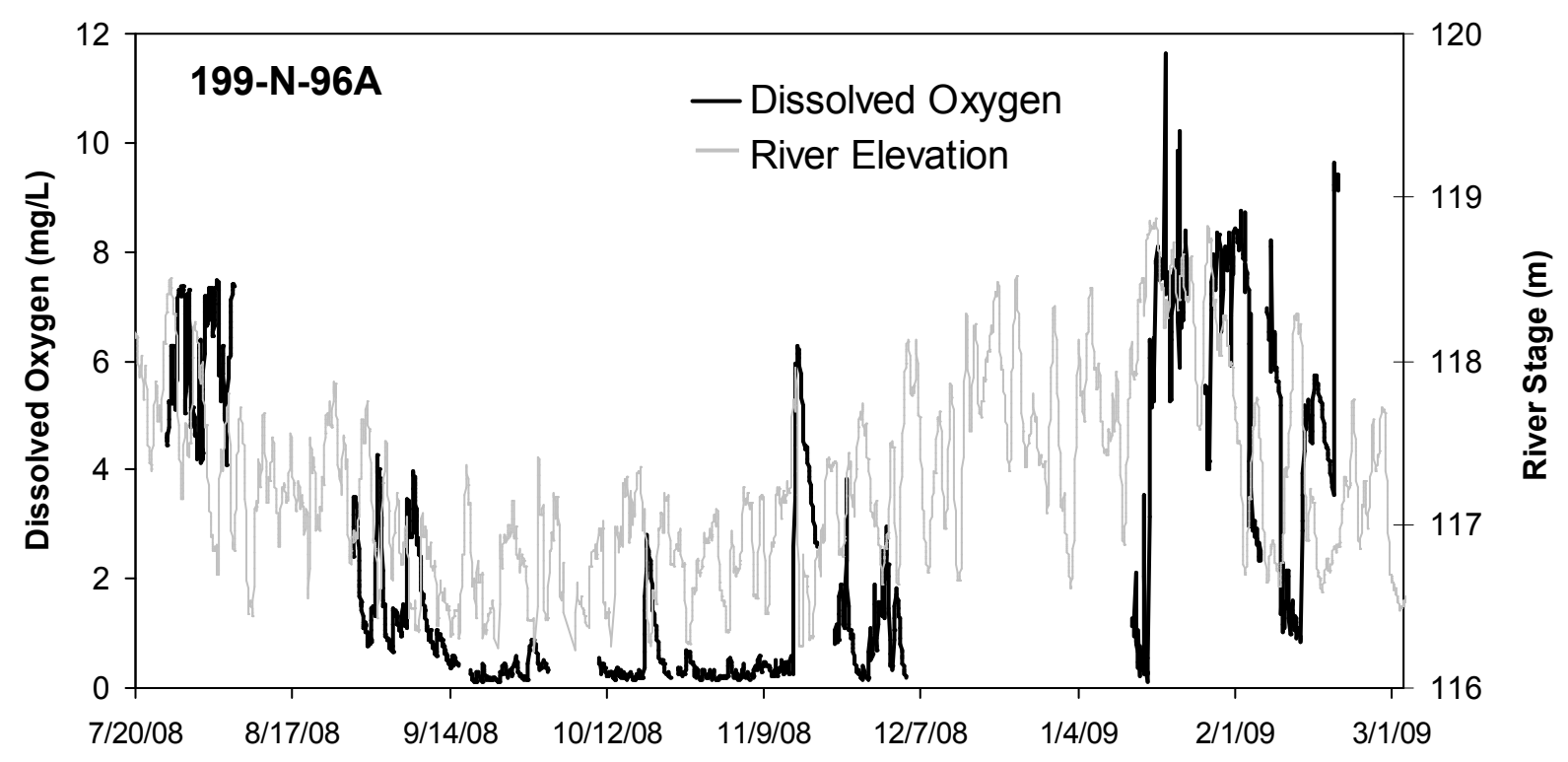

Figure 6. Dissolved Oxygen Concentrations Measured in 199-N-96

This unusual pattern was further investigated by installing a pair of dissolved oxygen sensors in 199-N-96A; one near the bottom of the screen, and one near the top of the water table. During most time periods, the dissolved oxygen concentration was the same at the top and bottom of the screened interval (Figure 7). During some periods of rapid decrease in river stage, the top sensor measured an increase in dissolved oxygen concentration. The bottom sensor only measured a significant change in dissolved oxygen concentration a couple of times. One possible explanation for this unusual behavior is that 199 N-96A is on the very edge of the diesel contamination plume. During stable hydraulic conditions, microbial activity results in low dissolved oxygen concentrations. During rapid decreases in river stage, the hydraulic gradient changes such that water from outside of the diesel contamination plume (higher dissolved oxygen) moves into the well, primarily near the top of the water table. 


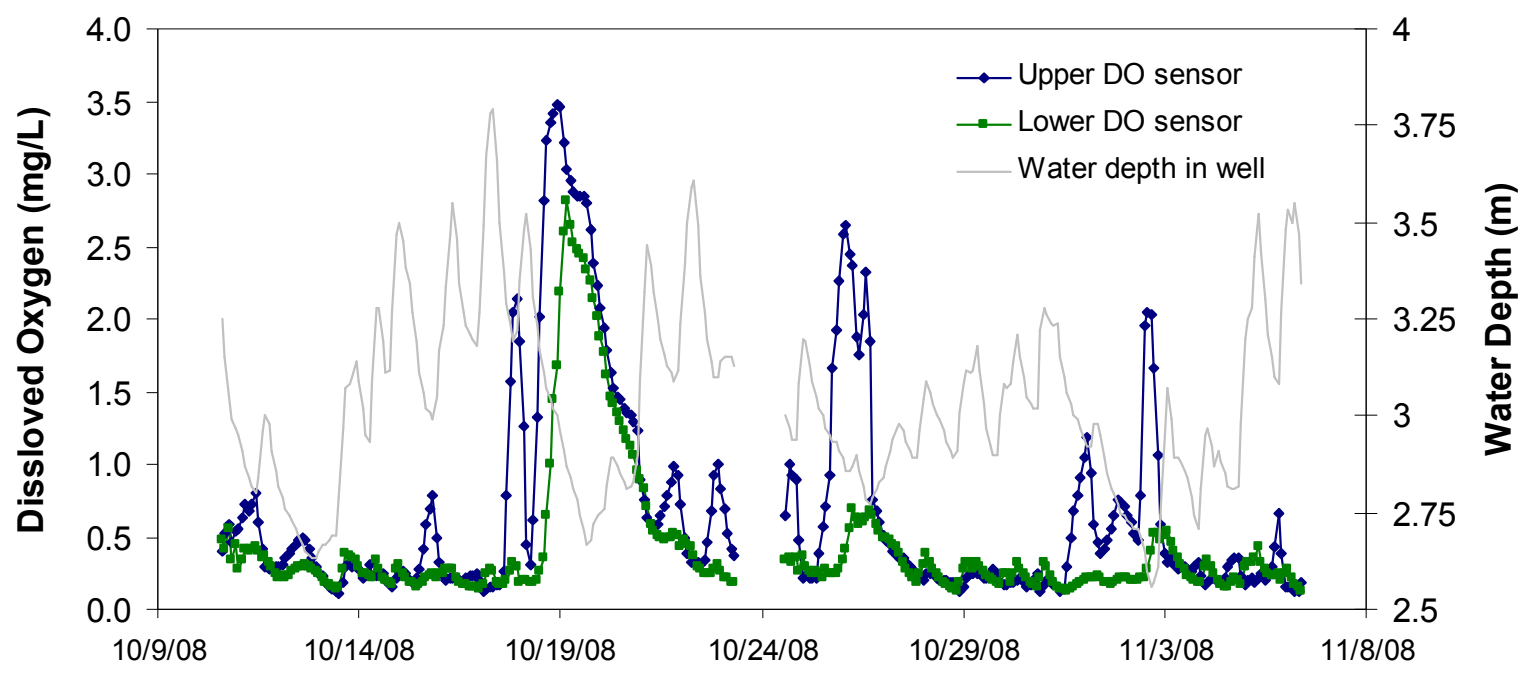

Figure 7. Dissolved Oxygen Measured at Two Locations in 199-N-96A; Near the Top and Bottom of the Screened Interval

\subsection{Microbial Assessment}

Several sediments samples from well 199-N-173 that were found to be contaminated with TPH were sent to Washington State University, Pullman to look at microbial populations and species. The objective was to determine if diesel-degrading microorganisms are present and if so, to test the microorganisms ability to break down TPH.

\subsubsection{Presence of Diesel degrading Bacteria}

Samples that appeared to have a substantial amount of TPH present were examined for dieseldegrading microorganisms and total heterotrophs using a modified most probable number (MPN) method. Assessment includes the use of "mini plates" (volume of agar $=1 \mathrm{~mL}$ ) in which serial dilutions of diesel laden soil were added. Plates that had positive growth were used to determine bacterial numbers based on the relative growth to dilution and were compared to standard tables used by the food and drug administration (Blodgett 2003). The two plates chosen to do the MPN test had sample material collected at depths of $15 \mathrm{ft}$ bgs and 17.5-20 ft bgs. The populations were averaged over five samples, and the results indicate that bacteria which have an ability to degrade diesel fuel are present (Table 7).

Table 7. Most Probable Number (MPN) Results for Bacteria Growth Using Two Sediment Samples Collected During Drilling of Monitoring Well 199-N-173

\begin{tabular}{cccc}
\hline & $\begin{array}{c}\text { MPN } \\
\text { Sample Depth (ft) }\end{array}$ & $\begin{array}{c}\text { Lower Confidence } \\
\text { Interval } \\
(\alpha=0.05)\end{array}$ & $\begin{array}{c}\text { Upper Confidence } \\
\text { Interval } \\
(\alpha=0.05)\end{array}$ \\
\hline $17.5-20$ & $3.5 \times 10^{4}$ & $1.0 \times 10^{4}$ & $1.1 \times 10^{5}$ \\
15 & $5.4 \times 10^{3}$ & $1.5 \times 10^{3}$ & $1.7 \times 10^{4}$ \\
\hline
\end{tabular}


In order to gain a better understanding of the morphology of the bacteria, regular agar plates were used to grow the bacteria. All bacteria were grown in the presence of diesel fuel $(0.05 \mathrm{~g}$ per plate). The plates were inoculated with a sediment suspension from each of the monitoring well samples and allowed to dry. Diesel fuel was then spread thinly over the agar plate to act as a carbon and energy source. The diesel fuel was obtained from a local gas station. The plates were then incubated for approximately 30 days at $30^{\circ} \mathrm{C}$ under aerobic conditions. After completion of the incubation, the agar plates were assessed for positive results. Numerous plates indicated the presence of bacteria (Figure 8). The upper left plate is bacteria grown from the $35 \mathrm{ft}$ bgs sediment, upper right is from sediment collected $17 \mathrm{ft} \mathrm{bgs,}$ lower left was inoculated with sediment from $15 \mathrm{ft}$ bgs, and the lower right sample used sediment from 17.5-20 ft bgs. Clearing zones appeared around all the colonies indicating diesel degradation had occurred (Figure 8). The white bacteria growth on plates A and B (Figure 8) demonstrate the production of rhamnolipids, which are natural surfactants produced by some bacteria to aid in the mobilization of organics. The rhamnolipids make the organic compounds more readily available for biodegradation by the bacteria. The presence of rhamnolipid producing bacteria also likely explains the foamy water observed purging of well 199-N-173 (Appendix C).

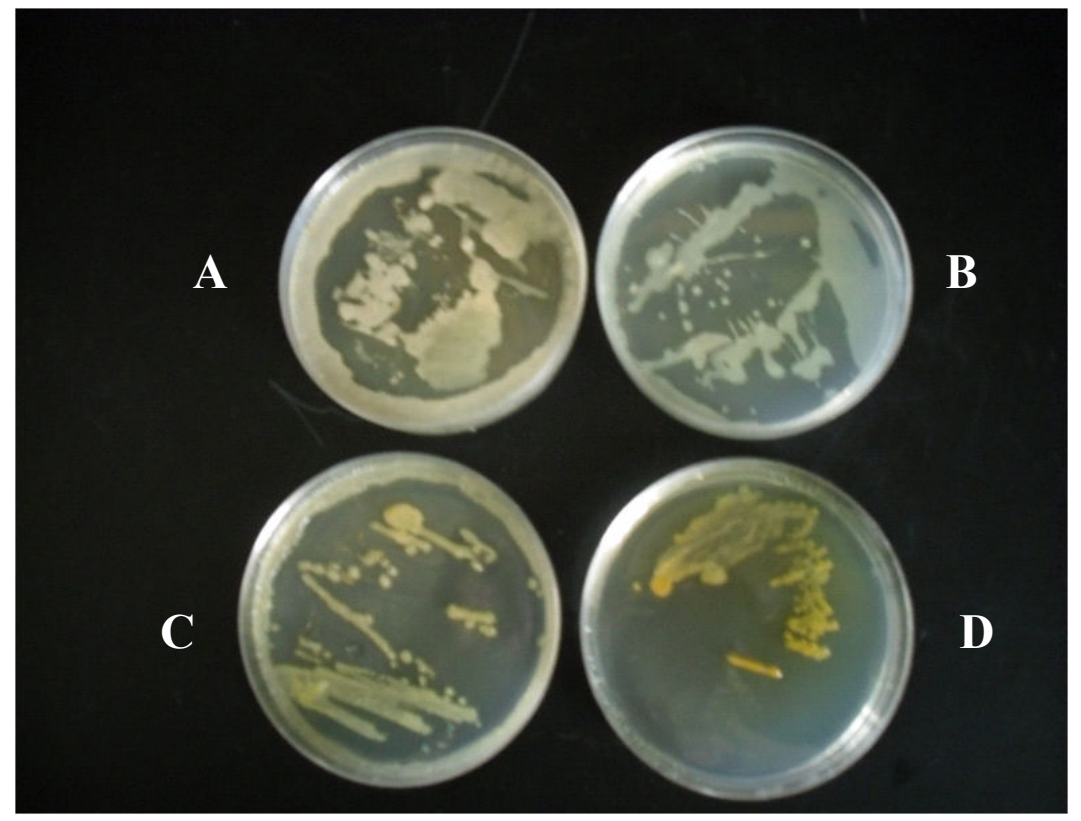

Figure 8. Agar Plates with Bacteria Growing on Them. Diesel fuel was the sole carbon source; sediment from: A-35 ft bgs, B- $17 \mathrm{ft}, \mathrm{C}-15 \mathrm{ft}, \mathrm{D}-17.5$ to $20 \mathrm{ft}$.

The two tests indicated that bacteria, capable of using diesel as the sole carbon source, are present in the soil. The use of the mini-plate was meant to enumerate all diesel degrading species that may have been present while the larger agar plate provides a qualitative indication of the types of bacteria present.

\subsubsection{Slurry Reactors}

Slurry rectors were used to determine the rate at which the bacteria could degrade diesel. Sediment from the $20 \mathrm{ft}$ bgs sample was used. Seven grams of soil (wet weight) and $110 \mathrm{~mL}$ of sterile (autoclaved) tap water were added to the reactors. A number of reactors were prepared and separated into different groups. The first group was used as a control; phosphate and ammonia $(0.62 \mathrm{mM}$ and $3.8 \mathrm{mM}$ 
respectively) were added along with $0.1 \mathrm{M}$ sodium azide to prevent bacterial growth. Other groups of reactors were prepared with nutrients (ammonia and phosphate), with nutrients and an additional carbon source (ammonia, phosphate and $500 \mathrm{mg} / \mathrm{L}$ molasses) and without nutrients. Reactors from different groups were sacrificed and total concentration of soil-phase diesel range organics (DRO) were determined by extraction/concentration in methylene chloride with quantification by gas chromatography/flame ionization detector (FID). The control and ammonia/phosphate reactors were prepared on March 2, 2009. Ammonia levels were maintained at constant levels throughout the experiment by monitoring ammonia concentrations and adding additional mass to maintain the target concentration.

After 17 days of incubation, the reactors were analyzed for diesel concentrations. The DRO concentrations were compared to the DRO concentrations in the sterile control reactors (Figure 9). Initial results demonstrate a reduction in diesel concentration for the reactors with nutrient addition relative to the control and the no-nutrient amendment. Repeat analysis reactors showed that the small apparent benefit of nutrient addition was not statistically significant relative to the no-nutrient tests. However, all of the slurry reactors demonstrated a statistically significant decrease in diesel concentration relative to the control. This indicates that natural attenuation of the diesel by microbial activity is occurring within the soil, enhancement or stimulation of the degradation process with the nutrients tried here would not be successful. 

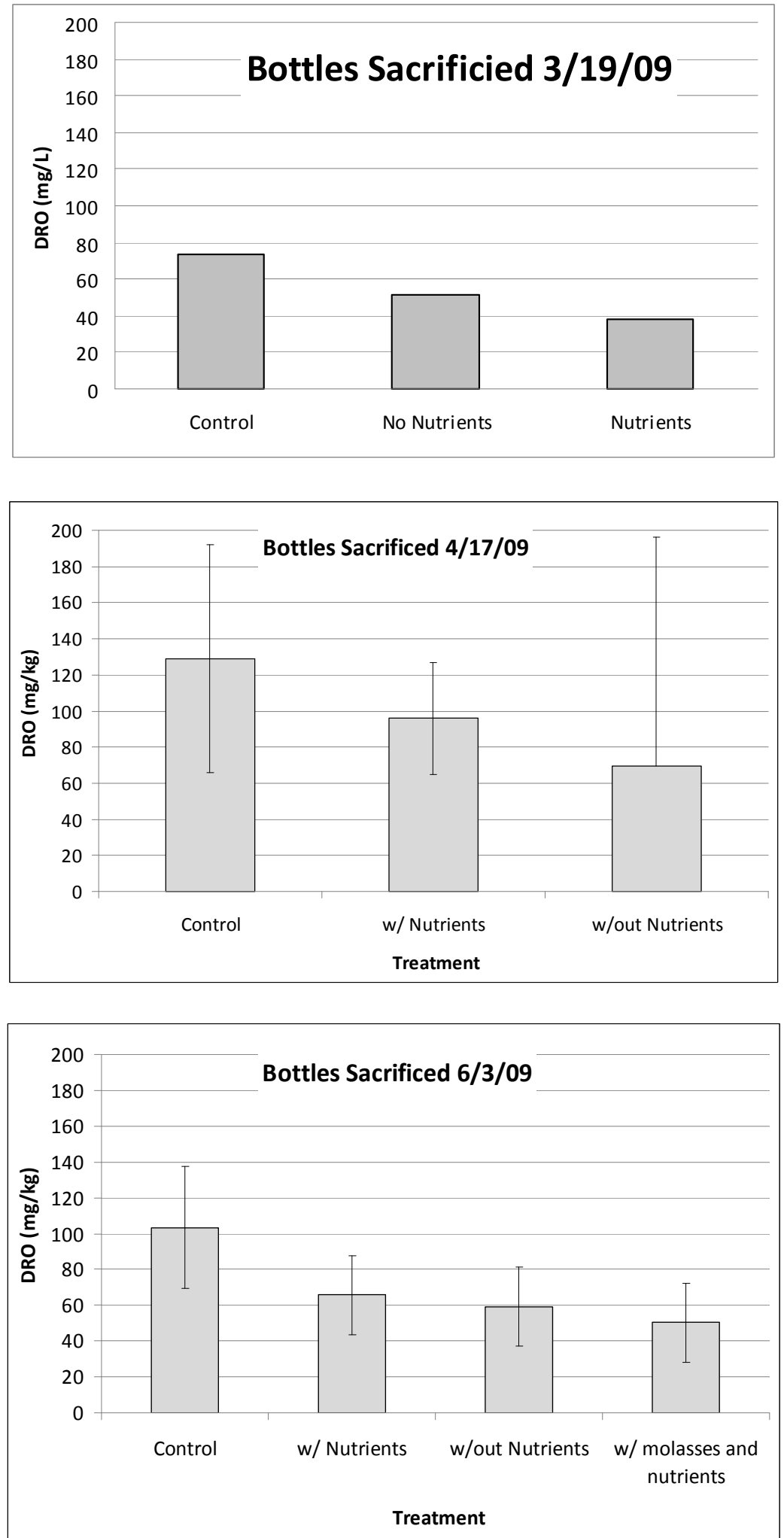

Figure 9. Results for Multiple Sets of Slurry Reactor Tests 


\subsection{Biota Assessment of TPH Plume}

Aquatic biota have been used to evaluate potential exposure to groundwater contaminants entering into a riverine environment. In particular, clams and periphyton have been used in the Hanford area to qualitatively determine if contaminated groundwater is entering into the Columbia River by analysis of body tissue for contaminants.

Periphyton and clam samples were collected from four locations along the $100-\mathrm{N}$ shoreline within the perceived TPH plume discharge boundary. Three periphyton and three clam samples were also collected at a reference location directly upstream of the plume (Figure 10). All samples were collected at the same river depth at the green line. The green line is the minimum river stage elevation along this stretch of the Columbia River (nominally $117 \mathrm{~m}$ ). The rocks on which the periphyton grow are always submerged, making for a high biological productivity area. The periphyton were scraped from the rocks immediately after the rocks were removed from the river. Clam samples were collected by plucking clams from the river bed. All samples were placed on ice after collection. The soft body tissues from 15-20 clams from each sampling location were removed from their shells in the laboratory within 6 hours of collection.

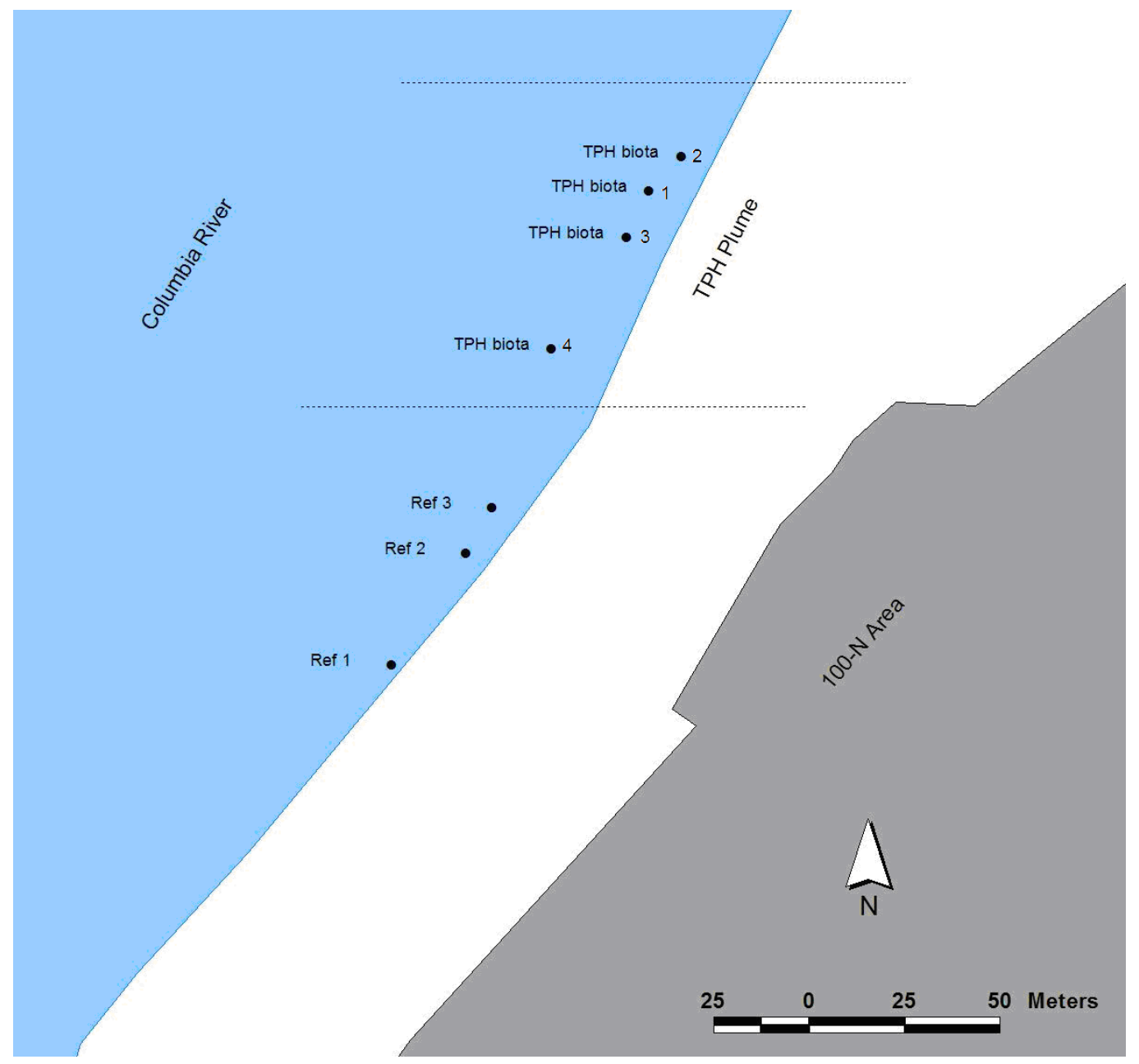

Figure 10. Periphyton and Clam Sampling Locations - September 2008 
Periphyton and clam tissue samples were analyzed for polycyclic aromatic hydrocarbons (PAH), a known byproduct of diesel fuel (ATSDR 1995). PAHs often attach to soil and sediment and are known to bioaccumulate in aquatic organisms, including invertebrates and periphyton (ATSDR 1995). Samples were submitted for analysis using EPA method 8720C. The PAHs that were analyzed are listed in Appendix A.

\subsubsection{Periphyton Results}

Three periphyton samples from the upstream reference location and four from the TPH plume were analyzed for PAHs . In most cases, results for individual PAHs were below detection $(0.5 \mathrm{ug} / \mathrm{kg})$. In all cases, average concentration results from the upstream reference area were the same as or higher than the average concentrations measured in periphyton samples collected from the suspected TPH plume discharge area (Table 8). This appears to be a result of the reference samples not being collected far enough upstream. For most of the periphyton results, the PAH concentrations reported at TPH location 4 and Reference location 1 were significantly higher than concentrations reported at the other five sampling locations. For example, fluorathene concentrations at these two locations were approximately 10 times higher than the concentration measured at the other five sampling locations (Figure 11). This trend was similar for all the PAHs measured at detectable concentrations.

Table 8. Average PAH Results for Periphyton Samples Collected within the $100 \mathrm{~N}$ TPH Plume and at an Upstream Reference Location - September 2008 (ug/kg wet weight)

\begin{tabular}{ccc}
\hline Analyte & Reference Location $^{\mathrm{a}}$ & TPH Plume $^{(\mathrm{a})}$ \\
\hline Anthracene & $2.3(\mathrm{n}=1)$ & $1.2(\mathrm{n}=1)$ \\
\hline Benz(a)anthracene & $0.56-5.1(\mathrm{n}=3)$ & $0.52-4.9(\mathrm{n}=2)$ \\
\hline Benzo(a)pyrene & $3.2(\mathrm{n}=1)$ & $3.1(\mathrm{n}=1)$ \\
\hline Benzo(b)fluoranthene & $0.57-5(\mathrm{n}=3)$ & $0.52-4.2(\mathrm{n}=3)$ \\
Benzo(g,h,i)perylene & $2.1(\mathrm{n}=1)$ & $1.4(\mathrm{n}=1)$ \\
\hline Benzo(k)fluoranthene & $2(\mathrm{n}=1)$ & $2(\mathrm{n}=1)$ \\
Chrysene & $0.54-6(\mathrm{n}=3)$ & $0.58-5(\mathrm{n}=2)$ \\
Fluoranthene & $0.93-12(\mathrm{n}=3)$ & $0.75-7.3(\mathrm{n}=4)$ \\
\hline Indeno(1,2,3-cd)pyrene & $2.3(\mathrm{n}=1)$ & $1.8(\mathrm{n}=1)$ \\
Phenanthrene & $0.57-7.2(\mathrm{n}=3)$ & $0.68-1.4(\mathrm{n}=4)$ \\
Pyrene & $0.69-11(\mathrm{n}=3)$ & $0.59-7.4(\mathrm{n}=3)$ \\
\hline
\end{tabular}

(a) The number of composite samples at the Reference Location was three, and at the TPH plume was four. NOTE: $\mathrm{n}=$ number of samples where analyte was above the detection limit $(0.5 \mathrm{ug} / \mathrm{kg})$ 


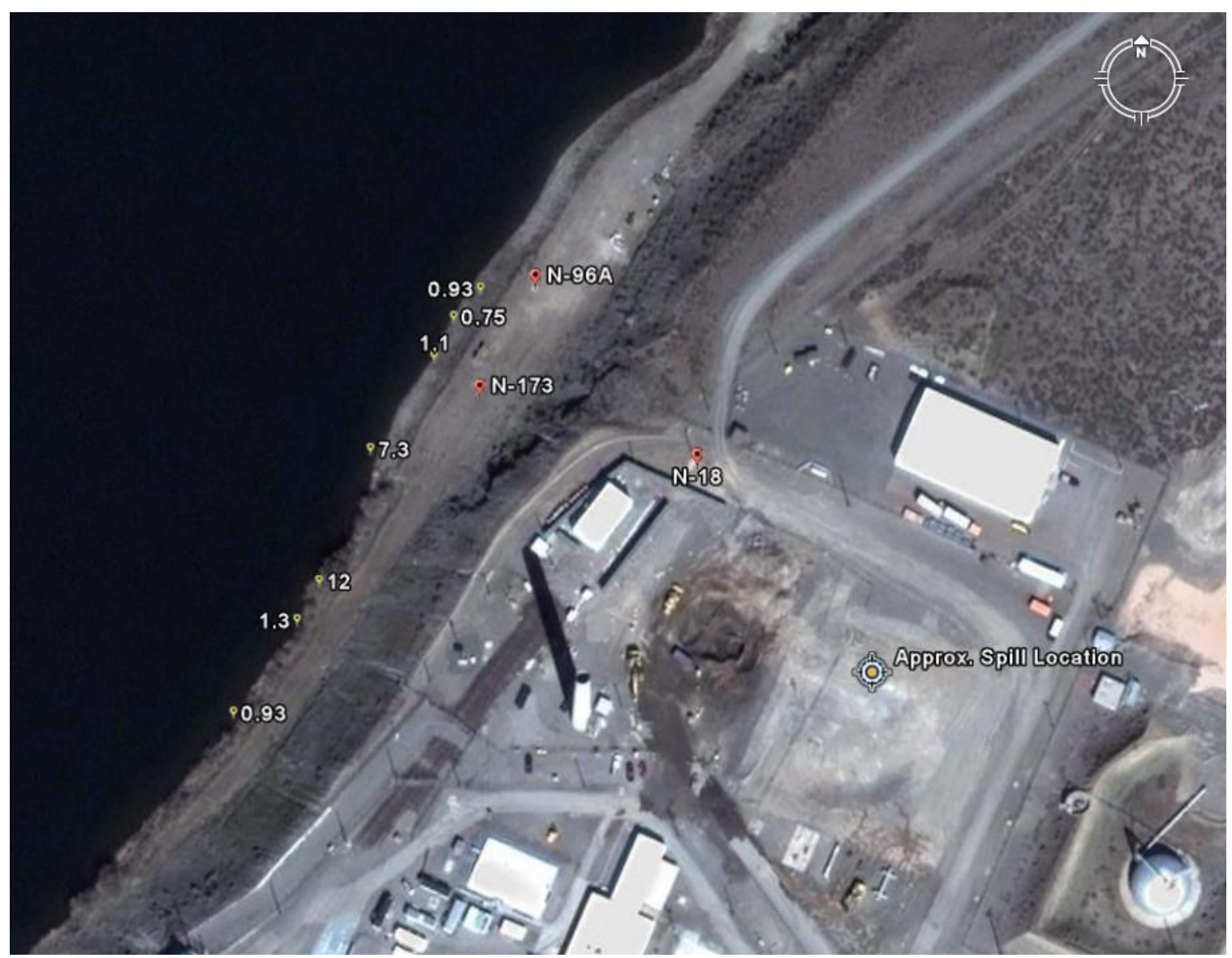

Figure 11. Fluorathene Concentrations Measured in Periphyton Samples Collected Along the 100-N Shoreline. Trend was similar for other PAHs.

\subsubsection{Clam Results}

Three clam tissue samples from the upstream reference location and four from the TPH plume were analyzed for PAHs (Table 9). One of the clam samples collected within the TPH plume had elevated levels of benz(a)anthracene, benzo(a)pyrene, benzo(b)fluoranthene, chrysene, and dibenzofuran compared to other clam samples collected in the TPH plume and at the upstream reference location. With the exception of dibenzofuran, the PAH levels for this clam sample were less than levels reported from the periphyton samples collected at the reference location and at the TPH plume. Dibenzofuran was only detected in the clam sample from the TPH plume (location 3). Four other compounds were measured at detectable concentrations at TPH location 4, but not detected at any of the reference locations. Unlike the periphyton results, concentrations measured in clams were similar at all sampling locations for those compounds with detectable concentrations at the reference locations. This implies that clams respond differently to PAHs than periphyton, as there is no strong evidence of increased PAH concentrations along the portion of shoreline sampled. 
Table 9. Average PAH Results for Clam Tissue Samples Collected within the $100 \mathrm{~N}$ TPH Plume and at an Upstream Reference Location - September 2008 (ug/kg wet weight)

\begin{tabular}{ccc}
\hline Analyte & Reference Location $^{\mathrm{a}}$ & TPH Plume $^{(\mathrm{a})}$ \\
\hline Benz(a)anthracene & ND & $0.79(\mathrm{n}=1)$ \\
\hline Benzo(a)pyrene & ND & $0.64(\mathrm{n}=1)$ \\
Benzo(b)fluoranthene & ND & $0.62(\mathrm{n}=1)$ \\
Chrysene & ND & $0.71(\mathrm{n}=1)$ \\
Dibenzofuran & ND & $1.3(\mathrm{n}=1)$ \\
Fluoranthene & $2.8-4.1(\mathrm{n}=3)$ & $2.4-4(\mathrm{n}=4)$ \\
Phenanthrene & $1.3-1.4(\mathrm{n}=3)$ & $0.88-1.4(\mathrm{n}=4)$ \\
Pyrene & $0.69-0.7(\mathrm{n}=2)$ & $0.79-1.2(\mathrm{n}=4)$ \\
\hline
\end{tabular}

(a) The number of composite samples at the Reference Location was three, and at the TPH plume was four.

NOTE: $\mathrm{n}=$ number of samples where analyte was above the detection limit $(0.5 \mathrm{ug} / \mathrm{kg})$

$\mathrm{ND}=$ not detected

\subsubsection{Biota Assessment Discussion}

Periphyton and clam samples are relatively easy to collect, abundant and can provide a useful indication of elevated levels of contaminants at one point in time. Biota samples, such as clams and periphyton, provide a good indicator of environmental exposure because these organisms live at the point where the groundwater contamination is highest as it enters the riverine environment. Many of the TPH constituents included in the PAH analyses are known to impact aquatic organisms in sediments and are regulated (EPA 2006). Uptake of PAHs in periphyton and clams indicate exposure of the organisms to the constituent through the water pathway. In addition, clams consume periphyton, and thus accumulation of PAHs in the clam is an indication of exposure through the food pathway.

With the exception of dibenzofuran, the PAHs that were detected in either the clams or the periphyton samples from the TPH plume were also detected in periphyton and clam samples from the upstream reference location. These results indicate that PAHs are accumulating in biota tissue in the $100-\mathrm{N}$ riverine environment. While the periphyton results indicate a potential groundwater source of PAHs, these results do not provide sufficient spatial or temporal coverage to delineate the source of the PAHs. The two periphyton samples with elevated PAH concentrations were collected along a stretch of shore with a strong eddy. The results could be an indication of increased PAH accumulation along that stretch of shore as a result of sediment accumulation caused by the eddy. 


\subsection{Discussion}

\subsection{Comparison of Well and Shoreline Core Results}

The concentrations of diesel in sediment measured in core samples from N-173 were compared against the concentrations measured along the shoreline. When compared spatially, the concentrations are relatively consistent at the two locations (Figure 12). The concentrations typically increase at lower elevations. The highest concentration measured at $199-\mathrm{N}-173$ was $140 \mathrm{mg} / \mathrm{kg}$ and occurred between 118.1 and 117.4 meters elevation. The two shoreline cores collected within this elevation range had measured diesel concentrations of 91 and $130 \mathrm{mg} / \mathrm{kg}$. However, TPH results from the shoreline core samples and from the well are not necessarily directly comparable. The well samples were bulk material, whereas the samples collected from shoreline cores were size selective; material larger than $\sim 5 \mathrm{~mm}$ was removed from the sample prior to analysis. For gravelly sediment, this could have biased the results from shoreline samples high.

Based on the field screening, the diesel concentration dropped below $15 \mathrm{mg} / \mathrm{kg}$ below $116.6 \mathrm{~m}$ elevation. The maximum sediment contamination may have been missed in 199-N-173 between 116.6 and 117.4 meters. This is the elevation range where the maximum TPH concentrations were measured in the shoreline core samples. However, the water sample collected at $116.4 \mathrm{~m}$ had lower measured diesel concentrations than the sample collected at $117.7 \mathrm{~m}$. It is also worth noting that $116.6 \mathrm{~m}$ is at approximately the $5^{\text {th }}$ percentile river state elevation; in other words, in the vicinity of $100-\mathrm{N}$, the river elevation only drops below 116.6 meters elevation about $5 \%$ of the time.

When all of these results are evaluated together, it would appear to indicate that the diesel contamination is confined to the 'smear zone', or that portion of the vadose zone that is occasionally saturated. This is not too surprising since diesel has a lower specific gravity than water. It would tend to float on top of the water table, making it less likely for sorption onto sediment to occur below the low water table elevation. It is important to note that the water samples collected along the shoreline were collected at elevations ranging between 116 and 117 meters, or likely near the bottom edge of the vertical extent of diesel contamination. 


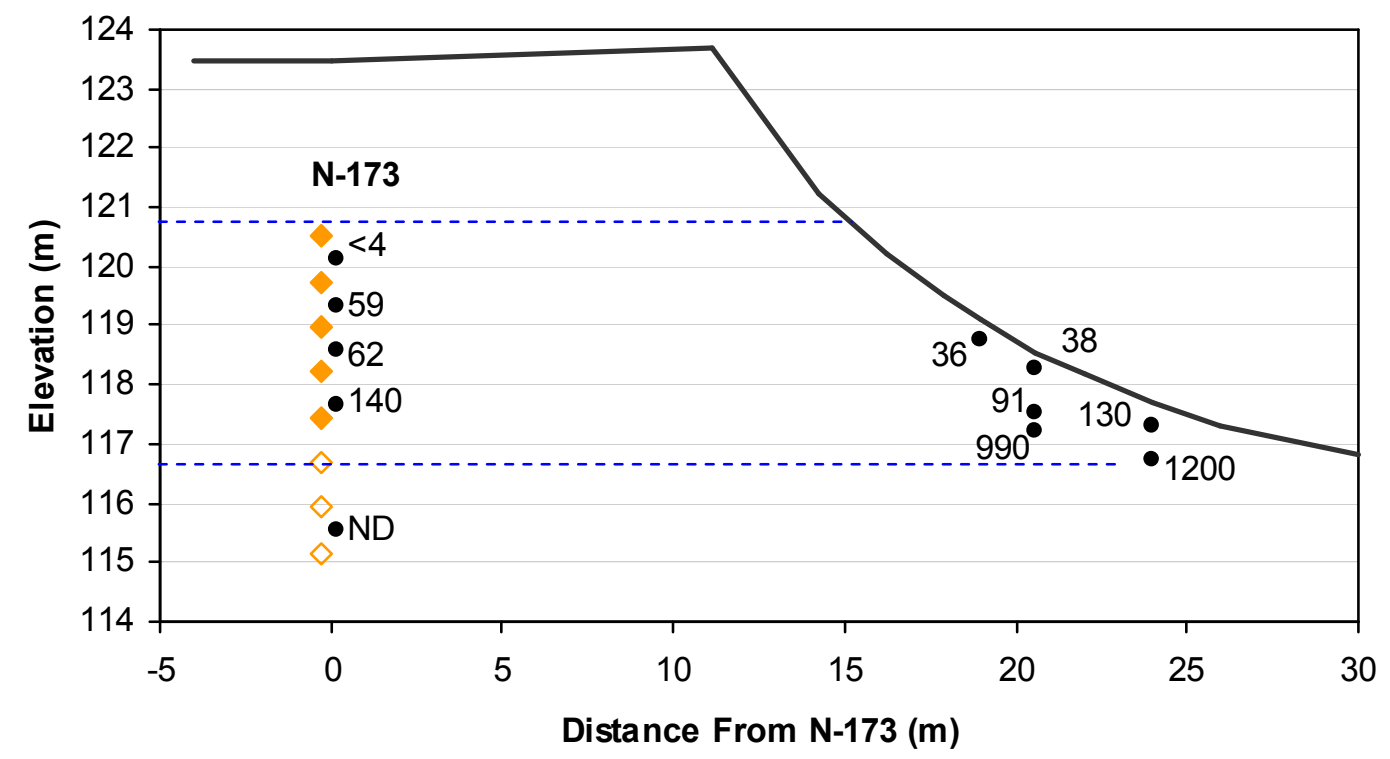

Figure 12. Concentrations of TPH-Dx measured in Sediment Samples Collected during Drilling of 199-N-173 and Along the Shoreline. Orange diamonds indicate where screening samples were collected ( solid $=$ detected, hollow $=$ undetected). The blue lines represent nominal high and low water table elevations.

\subsection{Comparison of Water Concentrations}

The results of water samples collected from well 199-N-173 during drilling were compared to historical results from the two closest groundwater monitoring wells (199-N-96A and 199-N-18). These two wells are located 45 meters cross gradient and 75 meters up-gradient from 199-N-173, respectively. The measured diesel concentrations in water were significantly higher in 199-N-18 than in wells 199-N173 and -96A (Table 10). Well 199-N-18 is located up-gradient from well 199-N-173, nominally halfway between the river and the plume origin. The significant decrease in diesel concentration between well $199-\mathrm{N}-18$ and the two other monitoring wells indicates that biological degradation of the diesel is likely occurring. Ethylbenzene and xylene concentrations were also lower at 199-N-173 than in 199-N-18, although the concentrations in 199-N-173 were not detectable. This could be a result of biological activity reducing ethylbenzene and xylene concentrations. Wells 199-N-173 and 199-N-18 had similar measured concentrations of iron, benzene. 199-N-96A had lower concentrations of iron, and no reported results for volatile compounds. On the other hand, 199-N-96A and 199-N-173 had similar concentrations of sulfate and nitrate, while 199-N-18 had much lower concentrations of these compounds. This is likely a result of a desalination effluent plume that is known to exist along that portion of the Columbia River shoreline (Mendoza et al. 2007). Although there is a minimal amount of analytical data available for contaminants in this plume, it would appear that by the time the plume reaches the near shore region, microbial activity has destroyed much of the diesel contamination. On the other hand, it would appear that benzene, and toluene concentrations are reduced at a slow rate through natural process. 
Table 10. Average Measured Concentrations of Several Key Analytes from Samples Collected in Recent Years in Monitoring Wells within the Suspected Footprint of the Diesel Contamination Plume ( $\mathrm{mg} / \mathrm{L})$

\begin{tabular}{|cccc}
\hline Constituent & $199-\mathrm{N}-173$ & $199-\mathrm{N}-96 \mathrm{~A}$ & $199-\mathrm{N}-18$ \\
\hline TPH-Dx & 3.2 & 1 & 632 \\
\hline Iron & 38 & 0.085 & 42 \\
\hline Sulfate & 154 & 76 & 7.8 \\
\hline Nitrate & 7.7 & 18 & 0.2 \\
\hline Benzene & 3 & $\mathrm{NS}$ & 0.95 \\
\hline Toluene & 2.5 & $\mathrm{NS}$ & 0.14 \\
\hline Ethylbenzene & $<1$ & NS & 3.9 \\
\hline Xylene & $<1$ & NS & 3.7 \\
\hline
\end{tabular}

\subsection{Comparison of Water, Sediment and Biota Concentrations}

Although there were several PAH compounds were detected in the biota samples, the only compounds measured at detectable concentrations in both biota and sediment samples were pyrene and fluoranthene. No PAHs were detected in any water samples collected by this project. While pyrene and fluoranthene were detected in one sediment sample each (although not the same sample) collected along the shoreline, the concentrations were below applicable standards. However, the elevated concentrations of PAHs measured in periphyton collected near the sediment samples appear to indicate a real source. There are several explanations for the elevated concentrations of PAHs identified upstream of 199-N-173 at the two periphyton sampling locations: 1) the diesel plume center is upstream of 199-N-173, 2) the PAHs moved towards the Columbia River along a different path than the diesel contamination, 3) the elevated PAH concentrations in periphyton are caused by a different groundwater source than the diesel spill, 4) elevated PAH concentrations in periphyton are a result of a contaminated Columbia River sediment (e.g., accumulation of sediment in an eddy). Further monitoring will be necessary to resolve this. 


\subsection{Conclusions/Recommendations}

This report summarizes a number of monitoring activities conducted around the known diesel contamination. It appears that microbial degradation of the diesel fuel contamination is occurring; the low dissolved oxygen and nitrate concentrations, the elevated soluble iron concentrations, the presence of rhamnolipid producing bacteria and the decrease in TPH concentrations observed in the slurry reactors all indicate that microbial activity is occurring within the footprint of the diesel contaminant plume. Since there are no other carbon sources, the bacteria must be using the residual contamination as a food source. It also appears that the concentrations of all contaminants in sediment and water are near or below applicable standards. However, the current data set is limited; monitoring for the key analytes needs to be conducted over several years to provide a better characterization of the concentrations. Also, the spatial distribution of the monitoring points is not adequate to characterize the average plume concentration, or to even identify the center and edges of the plume. For instance, the periphyton samples collected along the shoreline indicate that the plume centerline may be further upstream than previously suspected. Nevertheless, it is possible that (once a point-of-compliance is established) concentrations of contaminants within this plume will not exceed regulatory threshold concentrations. Therefore, the recommendations for immediate implementation are: a detailed conceptual model should be developed to provide a more complete picture of the contaminant fate and transport; work with regulators to establish the point-of-compliance for the TPH contaminant plume within the 100-NR-2 OU; consider quarterly monitoring of TPH (diesel fraction) as well as volatile organics and PAHs at wells within the suspected boundary of the contaminant plume, consider additional monitoring wells within the suspected boundary of the contaminant plume. 


\subsection{Reference}

ATSDR. 1995. Toxicological Profile for Polycyclic Aromatic Hydrocarbons, Agency for Toxic Substances and Disease Registry. Available at: http://www.atsdr.cdc.gov/toxprofiles/tp69.html

Blodgett, R. 2003. Bacteriological Analytical Manual (BAM), Appendix 2- Most Probable Number from Serial Dilutions. Available at:

http://www.fda.gov/Food/ScienceResearch/LaboratoryMethods/ucm109656.htm

EPA. 2006. Freshwater Sediment Screening Benchmarks. U.S. Environmental Protection Agency, Region III, Biological Technical Assistance Group. Available at:

http://www.epa.gov/reg3hwmd/risk/eco/btag/sbv/fwsed/R3_BTAG_FW_Sediment_Benchmarks_8$\underline{06 . p d f}$ 

Appendix A

Compounds Analyzed 

Table A.1. Analytical Methods Used for Sample Analysis

\begin{tabular}{|c|c|c|c|c|}
\hline Analyte & Method & Matrix & $\begin{array}{l}\text { Maximum } \\
\text { Hold Time }\end{array}$ & Detection Limit \\
\hline TPH-Dx ${ }^{(a)}$ & NWTPH-Dx & Water/Sediment & 14 days & $0.5 \mathrm{mg} / \mathrm{L}$ or $10 \mathrm{mg} / \mathrm{kg}$ \\
\hline TPH-Dx ${ }^{(b)}$ & EPA 8015 & Water/Sediment & 14 days & $0.5 \mathrm{mg} / \mathrm{L}$ or $10 \mathrm{mg} / \mathrm{kg}$ \\
\hline VOC & EPA 8260 & Water & 14 days & $1 \mathrm{mg} / \mathrm{L}$ \\
\hline SVOC & EPA 8270 & Water/Sediment & 14 days & $1 \mathrm{mg} / \mathrm{L}$ or $10 \mathrm{mg} / \mathrm{kg}$ \\
\hline BTEX/MTBE & EPA 8021B & Water/Sediment & 14 days & $1 \mathrm{mg} / \mathrm{L}$ or $10 \mathrm{mg} / \mathrm{kg}$ \\
\hline Anions & EPA 300.0 & Water & 45 days & $1 \mathrm{mg} / \mathrm{L}$ \\
\hline Metals & EPA 200.8 & Water & 60days & $1 \mathrm{mg} / \mathrm{L}$ \\
\hline Metals & EPA 6020 & Sediment & 60 days & $5 \mathrm{mg} / \mathrm{kg}$ \\
\hline PAH's & EPA $8270 \mathrm{C}$ & Water/Sediment & 14 days & $1 \mathrm{mg} / \mathrm{L}$ or $10 \mathrm{mg} / \mathrm{kg}$ \\
\hline PAH's & EPA $3541 /$ EPA $8270 C$ & Biota & 14 days & $1 \mathrm{ug} / \mathrm{kg}$ wet wt \\
\hline PCB's & EPA $608 / 8082$ & Water/Sediment & 14 days & $1 \mathrm{mg} / \mathrm{L}$ or $10 \mathrm{mg} / \mathrm{kg}$ \\
\hline
\end{tabular}

Table A.2. Compounds Analyzed for During the Various Sampling Efforts. Analytes with bolded text were measured at detectable concentrations in at least one sample collected for this study.

\begin{tabular}{llll}
\hline \multicolumn{1}{c}{$\begin{array}{c}\text { Well Water \& Sediment } \\
\text { Analytes }\end{array}$} & \multicolumn{1}{c}{$\begin{array}{c}\text { Near-Shore Water } \\
\text { Analytes }\end{array}$} & \multicolumn{1}{c}{$\begin{array}{c}\text { Near-Shore Sediment } \\
\text { Analytes }\end{array}$} & \multicolumn{1}{c}{$\begin{array}{c}\text { Clam \& Periphyton } \\
\text { Analytes }\end{array}$} \\
\hline 1,1,1-Trichloroethane & 1,1,1-Trichloroethane & 1,2,4-Trichlorobenzene & acenaphthene \\
1,1,2,2-Tetrachloroethane & 1,1,2-Trichloroethane & 1,3-Dichlorobenzene & acenaphthylene \\
1,1,2-Trichloroethane & 1,1-Dichloroethane & 1,4-Dichlorobenzene & anthracene \\
1,1-Dichloroethane & 1,1-Dichloroethene & 2,4,5-Trichlorophenol & benz[a]anthracene \\
1,1-Dichloroethene & 1,2-Dichloroethane & 2,4,6-Trichlorophenol & benzo[a]pyrene \\
1,2,4-Trichlorobenzene & 1,4-Dichlorobenzene & 2,4-Dichlorophenol & benzo[e]pyrene \\
1,2-Dichlorobenzene & 1,4-Dioxane & 2,4-Dimethylphenol & benzo[b]fluoranthene \\
1,2-Dichloroethane & 1-Butanol & 2,4-Dinitrophenol & benzo[g,h,i]perylene \\
1,2-Dichloroethene (Total) & 1-Methylnaphthalene & 2,4-Dinitrotoluene & benzo[j]fluoranthene \\
1,2-Dichloropropane & 2-Butanone & 2,6-Dinitrotoluene & benzo[k]fluoranthene \\
1,3-Dichlorobenzene & 2-Methylnaphthalene & 2-Chloronaphthalene & chrysene \\
1,4-Dichlorobenzene & 2-Pentanone, 4-Methyl & 2-Chlorophenol & dibenz[a,h]anthracene \\
\hline
\end{tabular}


Table A.2. contd

\begin{tabular}{|c|c|c|c|}
\hline $\begin{array}{c}\text { Well Water \& Sediment } \\
\text { Analytes }\end{array}$ & $\begin{array}{c}\text { Near-Shore Water } \\
\text { Analytes }\end{array}$ & $\begin{array}{c}\text { Near-Shore Sediment } \\
\text { Analytes }\end{array}$ & $\begin{array}{c}\text { Clam \& Periphyton } \\
\text { Analytes }\end{array}$ \\
\hline 2,4,5-Trichlorophenol & Acenaphthene & 2-Methylnaphthalene & fluoranthene \\
\hline 2,4,6-Trichlorophenol & Acenaphthylene & 2-Methylphenol & fluorene \\
\hline 2,4-Dichlorophenol & Acetone & 2-Nitroaniline & phenanthrene \\
\hline 2,4-Dimethylphenol & Anthracene & 2-Nitrophenol & pyrene \\
\hline 2,4-Dinitrophenol & Aroclor 1016 & 3,3'-Dichlorobenzidine & $\begin{array}{l}\text { indeno[ } 1,2,3- \\
c, d] p y r e n e\end{array}$ \\
\hline 2,4-Dinitrotoluene & Aroclor 1221 & 3-Nitroaniline & Dibenzofuran \\
\hline 2,6-Dinitrotoluene & Aroclor 1232 & 4,6-Dinitro-2-methylphenol & \\
\hline 2-Butanone & Aroclor 1248 & 4-Bromophenylphenyl ether & \\
\hline 2-Chloronaphthalene & Aroclor 1254 & 4-Chloro-3-methylphenol & \\
\hline 2-Chlorophenol & Aroclor 1260 & 4-Chloroaniline & \\
\hline 2-Hexanone & Benzene & 4-Chlorophenylphenyl ether & \\
\hline 2-Methylnaphthalene & Benzo(a)anthracene & 4-Methylphenol & \\
\hline 2-Methylphenol (cresol, o-) & Benzo(a)pyrene & 4-Nitroaniline & \\
\hline 2-Nitroaniline & Benzo(b)fluoranthene & 4-Nitrophenol & \\
\hline 2-Nitrophenol & Benzo(ghi)perylene & Acenaphthene & \\
\hline 2-Pentanone, 4-Methyl & Benzo(k)fluoranthene & Acenaphthylene & \\
\hline $3 \& 4$ Methylphenol Total & Carbon disulfide & Aluminum & \\
\hline 3,3'-Dichlorobenzidine & Carbon tetrachloride & Aniline & \\
\hline 3-Nitroaniline & Chloroform & Anthracene & \\
\hline 4,6-Dinitro-2-methylphenol & Chrysene & Benzene & \\
\hline 4-Bromophenylphenyl ether & cis-1,2-Dichloroethylene & Benzo(a)anthracene & \\
\hline 4-Chloro-3-methylphenol & Dibenzo(a,h)anthracene & Benzo(a)pyrene & \\
\hline 4-Chloroaniline & Ethyl cyanide & Benzo(b)fluoranthene & \\
\hline 4-Chlorophenylphenyl ether & Ethylbenzene & Benzo(ghi)perylene & \\
\hline 4-Nitroaniline & Fluoranthene & Benzo(k)fluoranthene & \\
\hline 4-Nitrophenol & Fluorene & Benzoic Acid & \\
\hline Acenaphthene & Indeno(1,2,3-cd)pyrene & Benzyl Alcohol & \\
\hline Acenaphthylene & Methylene chloride & Bis(2-Chloroethoxy)methane & \\
\hline Acetone & Naphthalene & Bis(2-chloroethyl) Ether & \\
\hline Anthracene & TPH-Dx & Bis(2-chloroisopropyl) Ether & \\
\hline
\end{tabular}


Table A.2. contd

\begin{tabular}{|c|c|c|c|}
\hline $\begin{array}{c}\text { Well Water \& Sediment } \\
\text { Analytes }\end{array}$ & $\begin{array}{c}\text { Near-Shore Water } \\
\text { Analytes }\end{array}$ & $\begin{array}{c}\text { Near-Shore Sediment } \\
\text { Analytes }\end{array}$ & $\begin{array}{c}\text { Clam \& Periphyton } \\
\text { Analytes }\end{array}$ \\
\hline Antimony & Phenanthrene & Bis(2-Ethylhexyl)phthalate & \\
\hline Benzene & Pyrene & Butylbenzylphthalate & \\
\hline Benzo(a)anthracene & Tetrachloroethene & Chrysene & \\
\hline Benzo(a)pyrene & Tetrahydrofuran & Cobalt & \\
\hline Benzo(b)fluoranthene & Toluene & Copper & \\
\hline Benzo(ghi)perylene & $\begin{array}{l}\text { trans-1,2- } \\
\text { Dichloroethylene }\end{array}$ & Dibenz(a,h)anthracene & \\
\hline Benzo(k)fluoranthene & Trichloroethene & Dibenzofuran & \\
\hline $\begin{array}{l}\text { Bis(2-Chloro-1- } \\
\text { methylethyl)ether }\end{array}$ & Vinyl chloride & $\begin{array}{l}\text { Diesel Range Organics } \\
\text { (DRO) }\end{array}$ & \\
\hline Bis(2-Chloroethoxy)methane & Xylenes (total) & Diethylphthalate & \\
\hline Bis(2-chloroethyl) ether & & Dimethyl phthalate & \\
\hline Bis(2-Ethylhexyl)phthalate & & Di-n-butylphthalate & \\
\hline Bromodichloromethane & & Di-n-octylphthalate & \\
\hline Bromoform & & Ethylbenzene & \\
\hline Bromomethane & & Fluoranthene & \\
\hline Butylbenzylphthalate & & Fluorene & \\
\hline Carbazole & & Hexachlorobenzene & \\
\hline Carbon disulfide & & Hexachlorobutadiene & \\
\hline Carbon tetrachloride & & Hexachlorocyclopentadiene & \\
\hline Chlorobenzene & & Hexachloroethane & \\
\hline Chloroethane & & Ideno(1,2,3-cd)pyrene & \\
\hline Chloroform & & Iron & \\
\hline Chloromethane & & Isophorone & \\
\hline Chrysene & & Lead & \\
\hline cis-1,3-Dichloropropene & & m,p-Xylenes & \\
\hline Cobalt- 60 & & Methyl-tert Butyl Ether & \\
\hline $\operatorname{Dibenz}(\mathrm{a}, \mathrm{h})$ anthracene & & Naphthalene & \\
\hline Dibenzofuran & & Nickel & \\
\hline Dibromochloromethane & & Nitrobenzene & \\
\hline Diethylphthalate & & N-Nitrosodimethylamine & \\
\hline Dimethyl phthalate & & n-Nitrosodi-n-propylamine & \\
\hline
\end{tabular}


Table A.2. contd

\begin{tabular}{|c|c|c|c|}
\hline $\begin{array}{c}\text { Well Water \& Sediment } \\
\text { Analytes }\end{array}$ & $\begin{array}{l}\text { Near-Shore Water } \\
\text { Analytes }\end{array}$ & $\begin{array}{l}\text { Near-Shore Sediment } \\
\text { Analytes }\end{array}$ & $\begin{array}{c}\text { Clam \& Periphyton } \\
\text { Analytes }\end{array}$ \\
\hline Di-n-butylphthalate & & n-Nitrosodiphenylamine & \\
\hline Di-n-octylphthalate & & o-Xylenes & \\
\hline Ethylbenzene & & Pentachlorophenol & \\
\hline Fluoranthene & & Phenanthrene & \\
\hline Fluorene & & Phenol & \\
\hline Hexachlorobenzene & & Potassium & \\
\hline Hexachlorobutadiene & & Pyrene & \\
\hline Hexachlorocyclopentadiene & & Residual Range Organics & \\
\hline Hexachloroethane & & Sodium & \\
\hline Ideno(1,2,3-cd)pyrene & & Toluene & \\
\hline \multicolumn{4}{|l|}{ Iron } \\
\hline \multicolumn{4}{|l|}{ Isophorone } \\
\hline \multicolumn{4}{|l|}{ Magnesium } \\
\hline \multicolumn{4}{|l|}{ Manganese } \\
\hline \multicolumn{4}{|l|}{ Methylene Chloride } \\
\hline \multicolumn{4}{|l|}{ Naphthalene } \\
\hline \multicolumn{4}{|l|}{ Nickel } \\
\hline \multicolumn{4}{|l|}{ Nitrate in Nitrogen } \\
\hline \multicolumn{4}{|l|}{ Nitrite in Nitrogen } \\
\hline \multicolumn{4}{|l|}{ Nitrobenzene } \\
\hline \multicolumn{4}{|l|}{ n-Nitrosodi-n-dipropylamine } \\
\hline \multicolumn{4}{|l|}{ n-Nitrosodiphenylamine } \\
\hline \multicolumn{4}{|l|}{ Pentachlorophenol } \\
\hline \multicolumn{4}{|l|}{ Phenanthrene } \\
\hline \multicolumn{4}{|l|}{ Phenol } \\
\hline \multicolumn{4}{|l|}{ Phosphorus in Phosphate } \\
\hline \multicolumn{4}{|l|}{ Pyrene } \\
\hline \multicolumn{4}{|l|}{ Strontium-89/90 } \\
\hline \multicolumn{4}{|l|}{ Styrene } \\
\hline \multicolumn{4}{|l|}{ Sulfate } \\
\hline \multicolumn{4}{|l|}{ Technetium-99 } \\
\hline \multicolumn{4}{|l|}{ Tetrachloroethene } \\
\hline Toluene & & & \\
\hline
\end{tabular}


Table A.2. contd

\begin{tabular}{|c|c|c|c|}
\hline $\begin{array}{c}\text { Well Water \& Sediment } \\
\text { Analytes }\end{array}$ & $\begin{array}{c}\text { Near-Shore Water } \\
\text { Analytes }\end{array}$ & $\begin{array}{l}\text { Near-Shore Sediment } \\
\text { Analytes }\end{array}$ & $\begin{array}{c}\text { Clam \& Periphyton } \\
\text { Analytes }\end{array}$ \\
\hline \multicolumn{4}{|l|}{ TPH- diesel range } \\
\hline \multicolumn{4}{|l|}{ TPH- kerosene range } \\
\hline \multicolumn{4}{|l|}{ trans-1,3-Dichloropropene } \\
\hline \multicolumn{4}{|l|}{ Trichloroethene } \\
\hline \multicolumn{4}{|l|}{ Trichlorofluoromethane } \\
\hline \multicolumn{4}{|l|}{ Tritium } \\
\hline \multicolumn{4}{|l|}{ Vinyl chloride } \\
\hline Xylenes (Total) & & & \\
\hline
\end{tabular}



Appendix B

\section{Analytical Results}



This appendix lists the raw analytical results. All results shown have no associated QC qualifiers. Samples with undetectable concentrations are reported here as 'ND'.

Table B.1. Shoreline Soil Samples

\begin{tabular}{|c|c|c|c|c|c|c|c|c|c|}
\hline $\begin{array}{l}\text { Analytes- results on a dry wt } \\
\text { basis }(\mathrm{mg} / \mathrm{kg})\end{array}$ & $\begin{array}{l}\text { TPHA1 } \\
2 \mathrm{ft}\end{array}$ & $\begin{array}{l}\text { TPHA2 } \\
1.5 \mathrm{ft}\end{array}$ & $\begin{array}{c}\text { TPHA2 } \\
4 \mathrm{ft}\end{array}$ & $\begin{array}{c}\text { TPHA2 } \\
5 \mathrm{ft}\end{array}$ & $\begin{array}{c}\text { TPHA3 } \\
2 \mathrm{ft}\end{array}$ & $\begin{array}{c}\text { TPHA3 } \\
4 \mathrm{ft}\end{array}$ & $\begin{array}{c}\text { TPHB1 } \\
2 \mathrm{ft}\end{array}$ & $\begin{array}{c}\text { TPHB1 } \\
4 \mathrm{ft}\end{array}$ & $\begin{array}{c}\text { TPHB1 } \\
5 \mathrm{ft}\end{array}$ \\
\hline Sample Elevation (m) & 118.8 & 118.3 & 117.5 & 117.2 & 117.3 & 116.7 & 118.1 & 117.5 & 117.2 \\
\hline Aluminum & 6170 & 8660 & 4520 & 5310 & 5710 & 5070 & 4510 & 4810 & 5270 \\
\hline Cobalt & 4.8 & 8.1 & 3.5 & 4.6 & 4.7 & 4.3 & 7.3 & 5.6 & 5.4 \\
\hline Copper & 11.5 & 13.3 & 9.9 & 10.4 & 11.9 & 13 & 11.1 & 18.7 & 11.8 \\
\hline Iron & 13300 & 16900 & 11700 & 12900 & 15200 & 13700 & 23400 & 20900 & 14700 \\
\hline Lead & 3.1 & 2.4 & 3.9 & 3.5 & 6.4 & 3.8 & 3 & 5.1 & 3.6 \\
\hline Nickel & 12.1 & 21.9 & 8.2 & 10 & 15 & 9.5 & 8.1 & 6.7 & 13.7 \\
\hline Potassium & 948 & 1220 & 746 & 900 & 645 & 567 & 404 & 465 & 688 \\
\hline Sodium & 115 & 484 & 153 & 184 & 293 & 267 & 239 & 262 & 218 \\
\hline TPH-Dx & 36 & 38 & 91 & 990 & 130 & 1200 & 320 & 350 & 690 \\
\hline residual range organics & 14 & 8.7 & 12 & 23 & 6.9 & 20 & 15 & 16 & 21 \\
\hline Methyl tert-butyl ether & ND & 0.083 & ND & ND & ND & ND & ND & ND & ND \\
\hline Benzene & 0.00071 & 0.0032 & ND & 0.00037 & 0.0025 & 0.00016 & 0.0011 & 0.00018 & 0.00034 \\
\hline Toluene & 0.00035 & 0.00068 & 0.00032 & 0.00073 & 0.00065 & 0.00038 & 0.00053 & 0.00021 & 0.00046 \\
\hline Ethylbenzene & 0.000059 & 0.000092 & ND & ND & ND & ND & 0.000076 & ND & 0.00013 \\
\hline m,p xylenes & 0.00018 & 0.0004 & 0.00021 & 0.00047 & 0.00037 & 0.00032 & 0.00033 & 0.00011 & 0.00025 \\
\hline o xylene & ND & 0.00016 & ND & 0.00025 & 0.00017 & ND & ND & ND & ND \\
\hline Fluoranthene & ND & ND & ND & NS & ND & ND & ND & ND & 0.015 \\
\hline Pyrene & ND & ND & ND & NS & ND & 0.024 & ND & ND & ND \\
\hline Bis(2-ethylhexyl) Phthalate & 0.034 & ND & 0.047 & NS & ND & ND & ND & 0.056 & 0.076 \\
\hline
\end{tabular}


Table B.2. Well Soil Samples

\begin{tabular}{|c|c|c|c|c|c|c|c|c|c|}
\hline $\begin{array}{l}\text { Analytes- results } \\
\text { on a dry wt basis } \\
\quad(\mathrm{mg} / \mathrm{kg})\end{array}$ & $\begin{array}{l}\text { B1YDD6/ } \\
\text { B1YDD8 }\end{array}$ & $\begin{array}{l}\text { B1YDF0/ } \\
\text { B1YDF2 }\end{array}$ & $\begin{array}{c}\text { Average }^{(\mathrm{a})} \\
\text { B1YDF4/B1YDF6 } \\
\text { B1YDH0/B1YDF8 }\end{array}$ & $\begin{array}{l}\text { B1YDH2/ } \\
\text { B1YDH4 }\end{array}$ & $\begin{array}{l}\text { B1YDH6/ } \\
\text { B1YDH8 }\end{array}$ & $\begin{array}{l}\text { B1YDJ0/ } \\
\text { B1YDJ2 }\end{array}$ & $\begin{array}{l}\text { B1YDJ4/ } \\
\text { B1YDJ6 }\end{array}$ & $\begin{array}{l}\text { B1YDJ8/ } \\
\text { B1YDK0 }\end{array}$ & $\begin{array}{c}\text { B1YDK2/ } \\
1 \text { YDK4 }\end{array}$ \\
\hline Depth (ft bgs) & $9.9-12$ & $12.5-14.5$ & $15-16.5$ & $17.5-20$ & $24.5-27$ & $30-31.5$ & $34.5-37$ & $39.5-42$ & $44.6-47.1$ \\
\hline $\begin{array}{l}\text { Elevation (middle } \\
\text { of core) }\end{array}$ & 120.1 & 119.3 & 118.6 & 117.7 & 115.5 & 114.0 & 112.5 & 111.0 & 109.4 \\
\hline Iron & 8750 & 15800 & 15150 & 14400 & 14000 & 7170 & 6020 & 14600 & 17900 \\
\hline Magnesium & 2350 & 3850 & 3425 & 2790 & 2150 & 2500 & 2690 & 2960 & 6660 \\
\hline Manganese & 92.5 & 165 & 198 & 158 & 178 & 145 & 0.0100 & 70.1 & 122 \\
\hline Nickel & 8.78 & 14.5 & 14.8 & 31.2 & 10.1 & 13.7 & $<0.00196$ & 4.10 & 16.2 \\
\hline TPH- Diesel & $N D<3.1$ & 59 & 61.5 & 140 & $N D<3.2$ & $N D<3.7$ & $N D<3.8$ & $N D<3.3$ & $N D<3.6$ \\
\hline $\begin{array}{l}\text { Bis(2-Ethylhexyl) } \\
\text { phthalate }\end{array}$ & $N D$ & $N D$ & 1.4 & 1.4 & 0.47 & 0.19 & 0.68 & 0.35 & 0.33 \\
\hline Benzene & $N D$ & 0.0028 & 0.003 & $N D$ & $N D$ & $N D$ & $N D$ & $N D$ & $N D$ \\
\hline Toluene & $N D$ & 0.0024 & 0.005 & $N D$ & $N D$ & $N D$ & $N D$ & $N D$ & 0.0028 \\
\hline Ethylbenzene & $N D$ & $N D$ & $N D$ & $N D$ & $N D$ & $N D$ & $N D$ & 0.0025 & $N D$ \\
\hline Xylenes & $N D$ & $N D$ & $N D$ & $N D$ & $N D$ & $N D$ & $N D$ & $N D$ & $N D$ \\
\hline Styrene & 0.0034 & 0.0031 & 0.0067 & 0.0036 & $N D$ & 0.0033 & 0.0035 & 0.0028 & 0.0039 \\
\hline 2-Butanone & $N D$ & $N D$ & 0.0073 & 0.0072 & $N D$ & $N D$ & $N D$ & $N D$ & $N D$ \\
\hline
\end{tabular}

(a)- Duplicate sample. Average of two samples is shown.

ND- Concentration reported below minimum detectable concentration. Detection Limit shown for TPH results. 
Table B.3. Water Samples

\begin{tabular}{cccccc}
\hline & \multicolumn{4}{c}{ HEIS Sample ID } \\
\cline { 2 - 6 } Constituent & B1YK44 & B1YK46 & B1YK48 & B1YK50 & B1YK54 \\
\hline Depth bgs $(\mathrm{ft})$ & 19 & 19 & 23.2 & 33 & 43 \\
Sp. Cond. $(\mu \mathrm{S} / \mathrm{cm})$ & 1420 & 1420 & 1216 & 1243 & 834 \\
TPH-Dx $(\mathrm{mg} / \mathrm{L})$ & 3.9 & 4.3 & 2.3 & $<0.07$ & 0.389 \\
Iron $(\mathrm{mg} / \mathrm{L})$ & 42.2 & 33.9 & 1.8 & 20.4 & 25.3 \\
Magnesium $(\mathrm{mg} / \mathrm{L})$ & 48.8 & 52.7 & 27.2 & & 207 \\
\hline
\end{tabular}



Appendix C

Drilling Information for Monitoring Well 199-N-173 



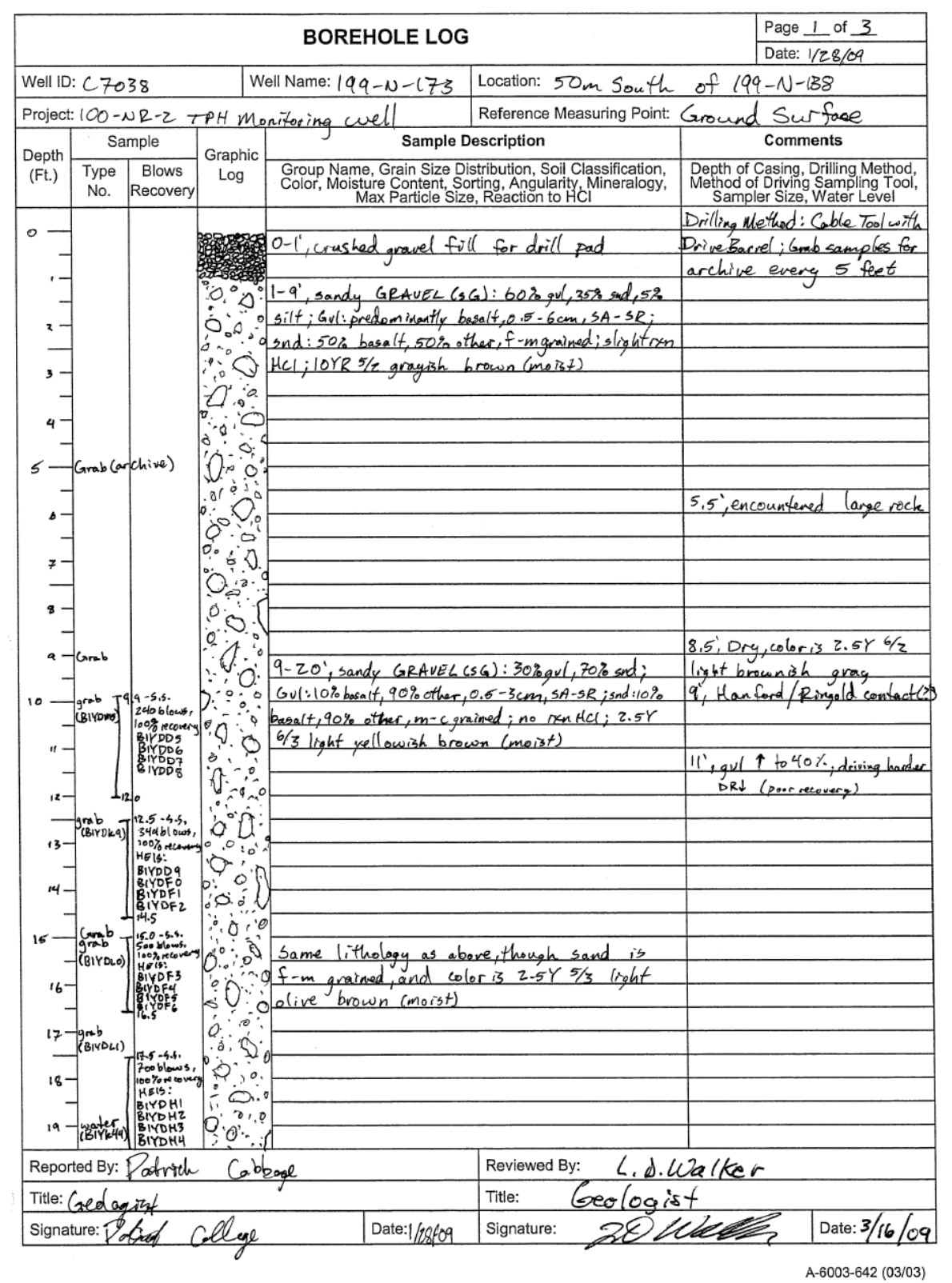

Figure C.1. Borehole Log for 199-N-173 


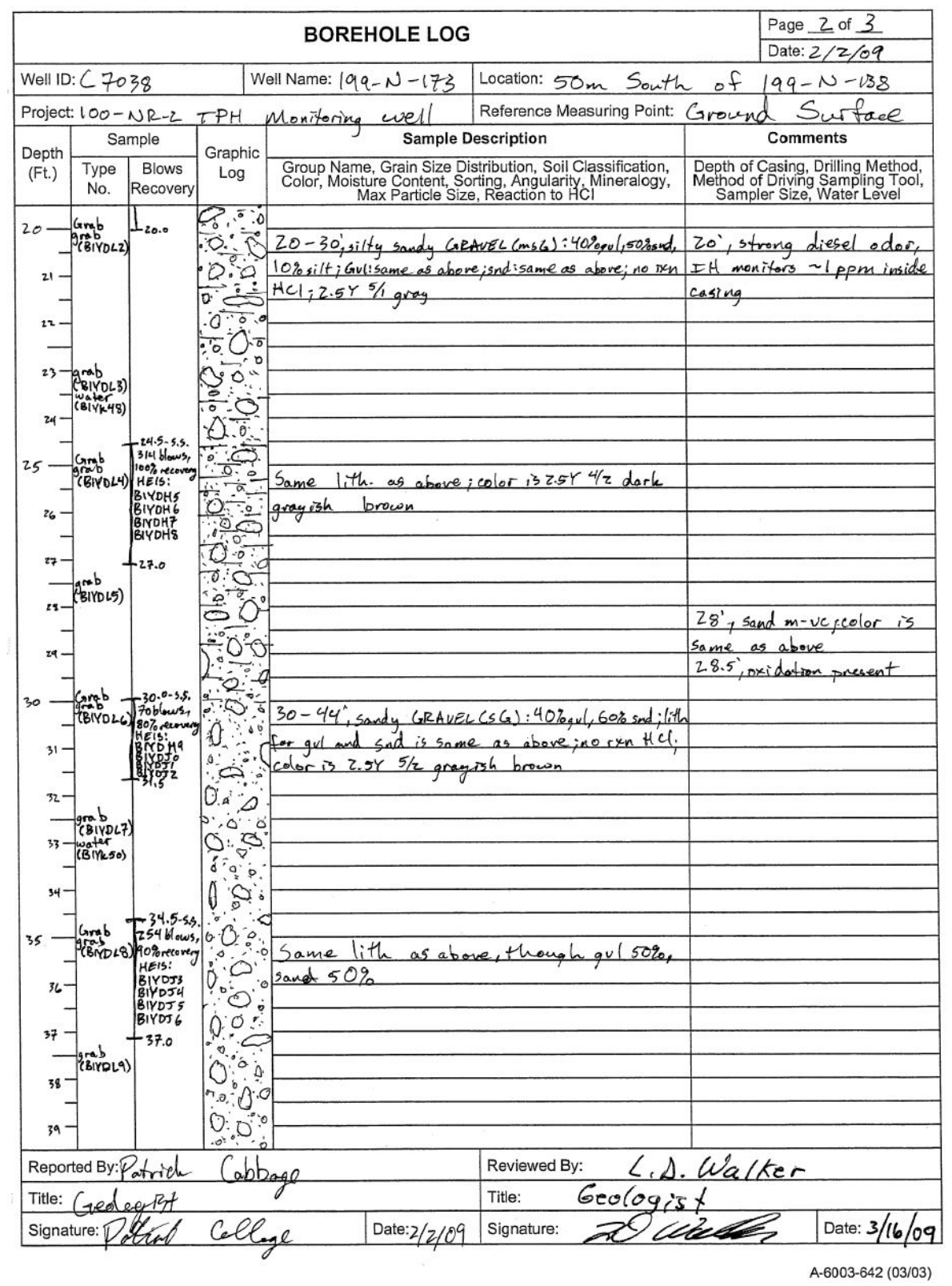

Figure C.1. contd 


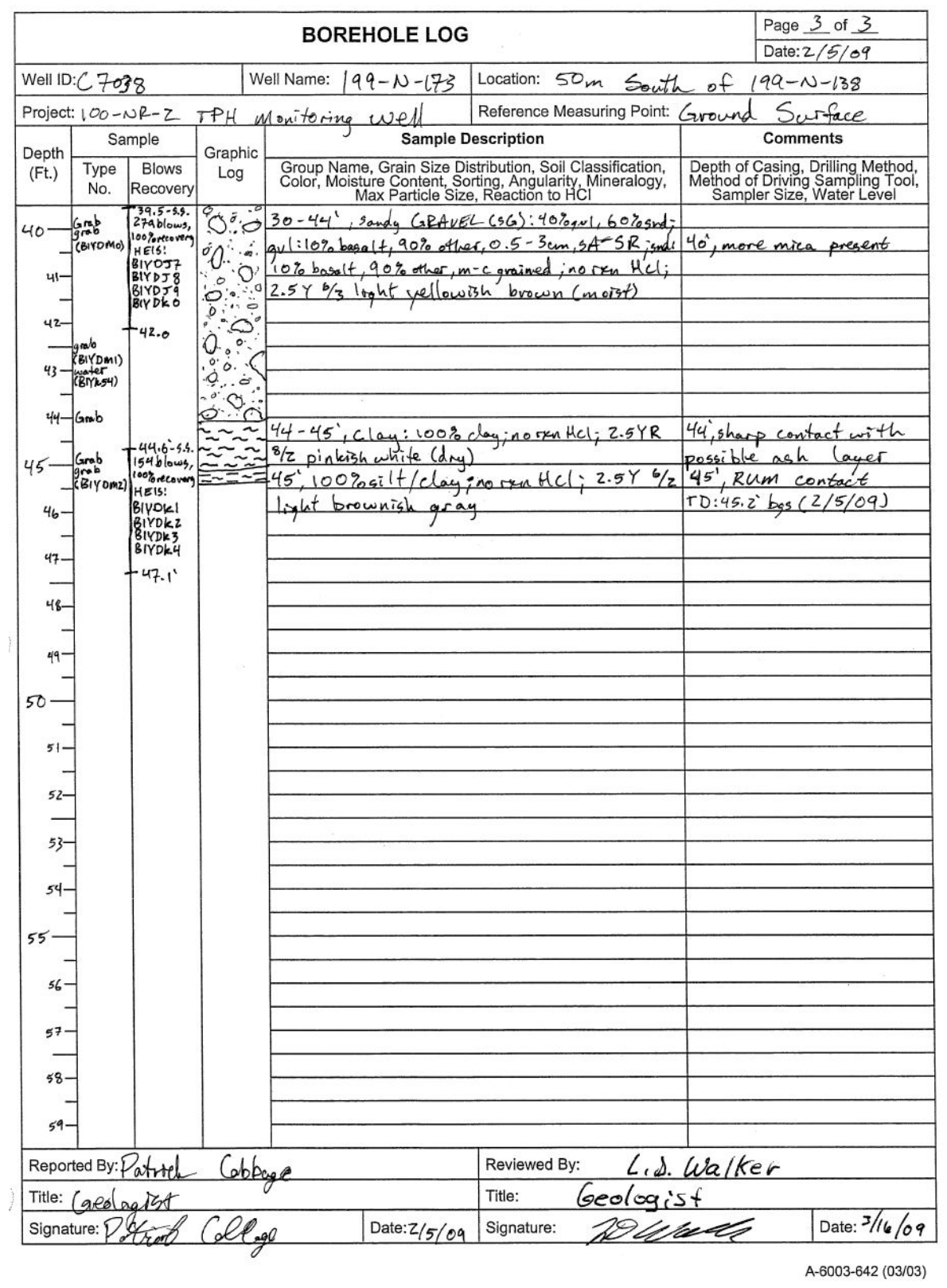

Figure C.1. contd 

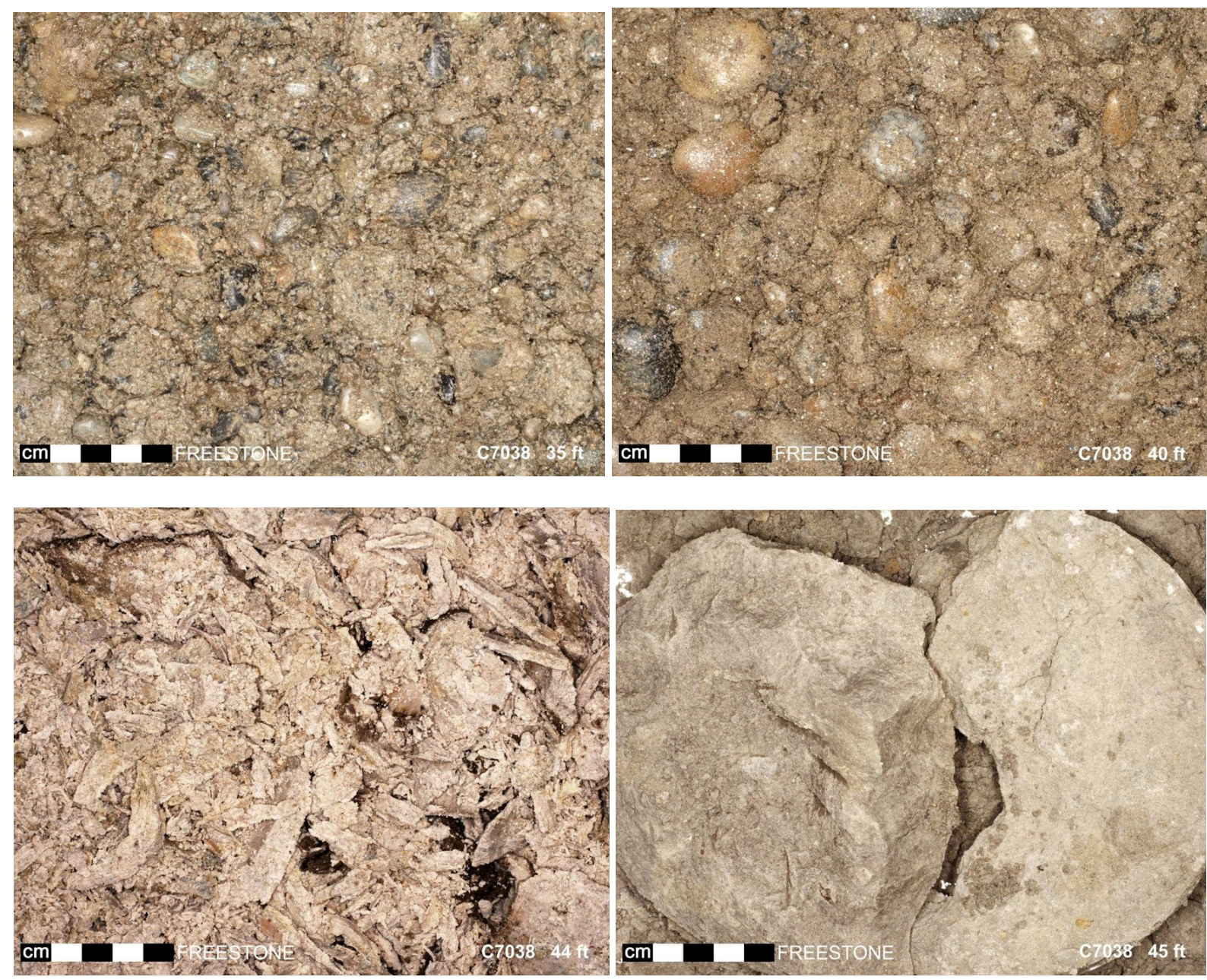

Figure C.2. Additional Pictures of Core Samples Collected From Monitoring Well 199-N-173 

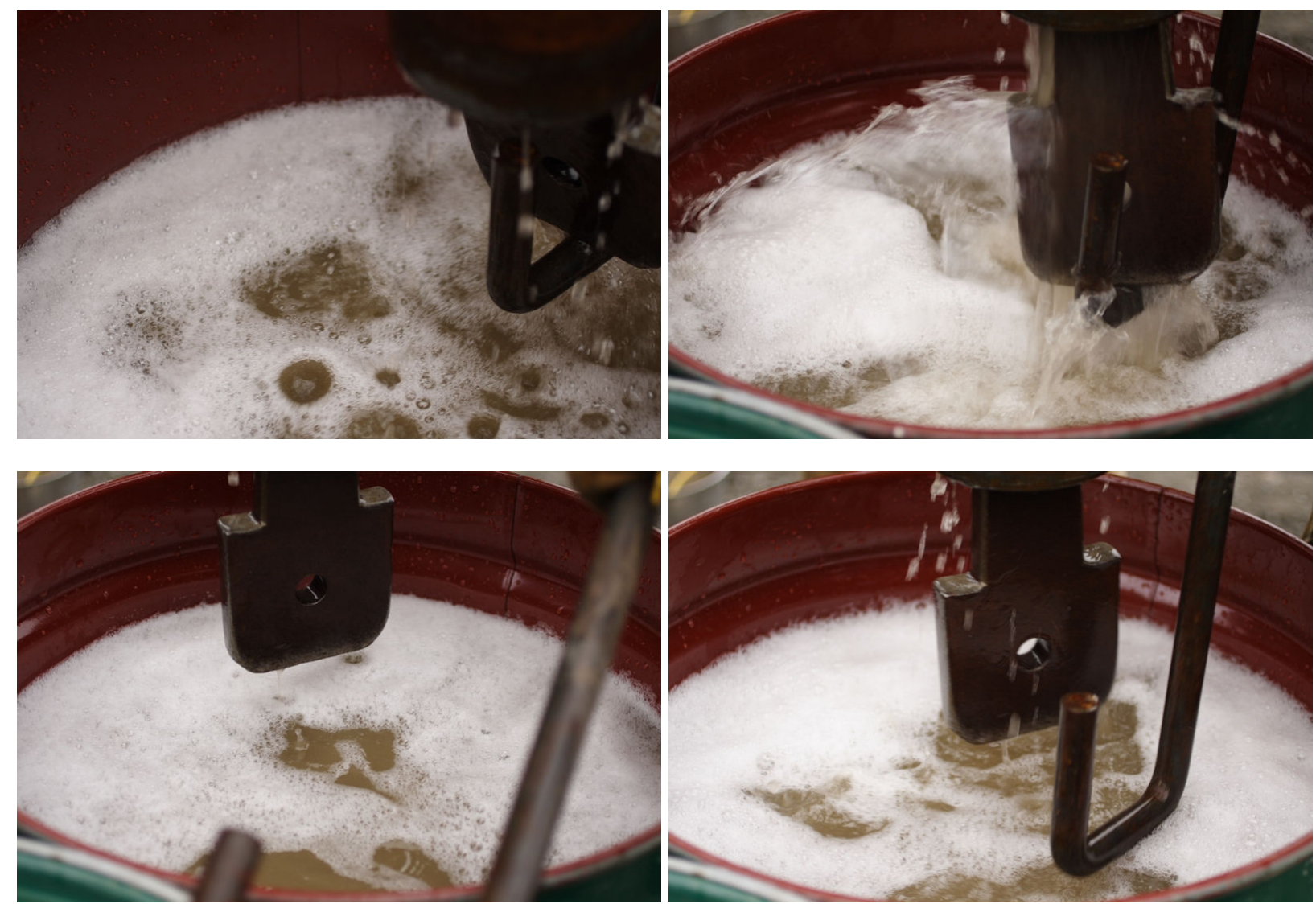

Figure C.3. Examples of the Unusual Foamy Water Observed During Drilling and Development of Monitoring Well 199-N-173 



\section{Distribution}

No. of

Copies

18 Local Distribution

12 Pacific Northwest National Laboratory RJ Cameron

BG Fritz (5)

DP Mendoza (5)

JA Stegen

K6-75

K6-96

K3-61
No. of

Copies

6 CHPRC

D Alexander R3-60

NA Bowles (5) R3-60

Distr.1 




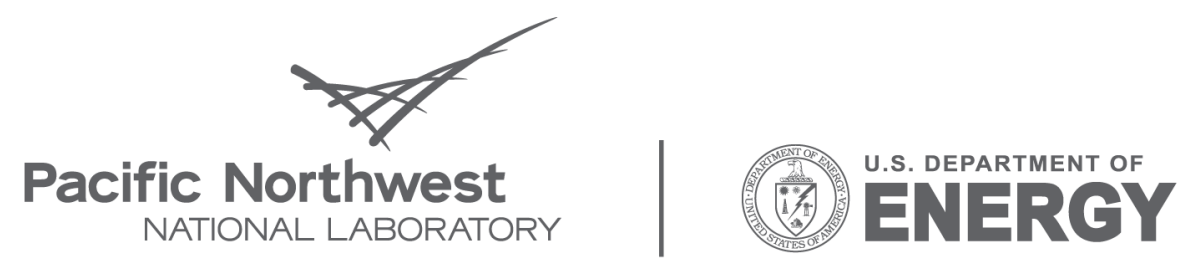

Proudly Operated by Battelle Since 1965

902 Battelle Boulevard

P.O. Box 999

Richland, WA 99352

1-888-375-PNNL (7665)

www.pnl.gov 